\title{
Fossil and modern sponge fauna of southern Australia and adjacent regions compared: inter- pretation, evolutionary and biogeographic significance of the late Eocene 'soft' sponges
}

\author{
Magdalena Łukowiak ${ }^{1,2}$ \\ ${ }^{1}$ Institute of Paleobiology PAN, Twarda 51/55, 00-818 Warszawa, Poland \\ ${ }^{2}$ E-mail: mlukowiak@twarda.pan.pl
}

Key words: Demospongiae, Homoscleromorpha, Porifera

\begin{abstract}
The late Eocene 'soft' sponge fauna of southern Australia is reconstructed based on disassociated spicules and is used to interpret the paleoecology and environmental context of shallow marine communities in this region. The reconstructed sponge association was compared with coeval sponge assemblages from the Oamaru Diatomite, New Zealand, and with the modern 'soft' sponge fauna of southern coastal of Australia. Based on the predominance of shallow- and moderately shallow-water species, the late Eocene assemblage is interpreted to have inhabited waters depths of about $100 \mathrm{~m}$. This contrast with the spicule assemblage from New Zealand, which characterized deeper waters based on the presence of numerous strictly deepwater sponge taxa, and the absence of spicules of shallow-water demosponges represented in the Australian material. The southern Australian Eocene sponge assemblages have clear Tethyan affinities evidenced by the occurrence of sponges known today from diverse regions. This distribution suggests much wider geographical ranges of some sponge taxa during the Eocene. Their present distributions may be relictual. The modern sponge fauna inhabiting southern Australian waters shows only moderate differences from these of the late Eocene. Differences are more pronounced at lower taxonomic levels (family and genus).
\end{abstract}

\section{Contents}

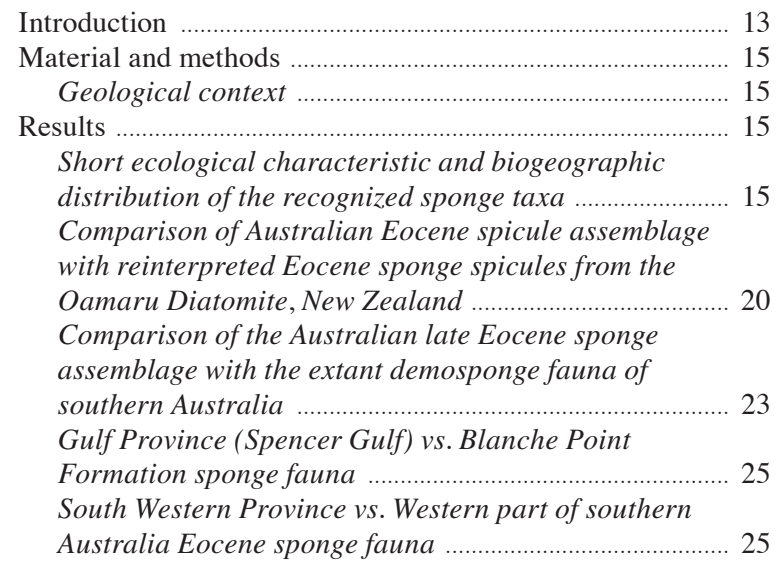

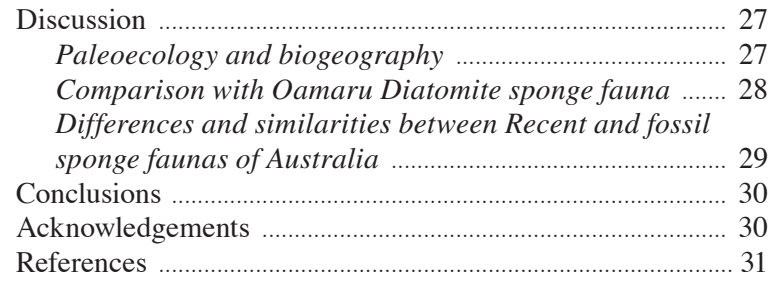

\section{Introduction}

Sponges are among the simplest metazoans and, thus, are crucial for understanding the origin of animals. Their fossil record dates back to the beginning of the Paleozoic Era (e.g. Hamdi et al., 1989; Brasier, 1989; Kaesler et al., 2004). Some early Vendian fossils have been noted as sponges (Reitner and Mehl, 1995; Hooper and van Soest, 2002), however, these findings were recently questioned (Antcliffe et al., 2014). Fossil sponges are cosmopolitan, preserved as both articulated bodies and isolated spicules. The quality of the sponge fossil record varies through geological time, but some exceptionally preserved and rich sponge (or spicule) associations may provide valuable information about the evolution of the group.

Fossil sponges and isolated spicules have been studied extensively since the nineteenth century (e.g. Goldfuss, 1826-33; Zittel, 1877; Roemer, 1860; Quenstedt, 1878; Hinde, 1883, 1893; Hinde and Holmes, 1892; Rauff, 1893-95; and Hall and Clarke, 1899; Mostler, 1972, 1976, 1994; Pisera, 2006 and references therein). The spicules were generally treated from the morphological point of view, as separate disassociated elements, and rarely attributed to particular taxa. Consequently, there are very few papers describing ecological relationships of sponge associations and these deal mostly with those associations from the northern part of the world (e.g., see Koltun, 1959, 1961; Pisera, 1997; Pisera and Busquets, 2002; Pisera and Hladilová, 


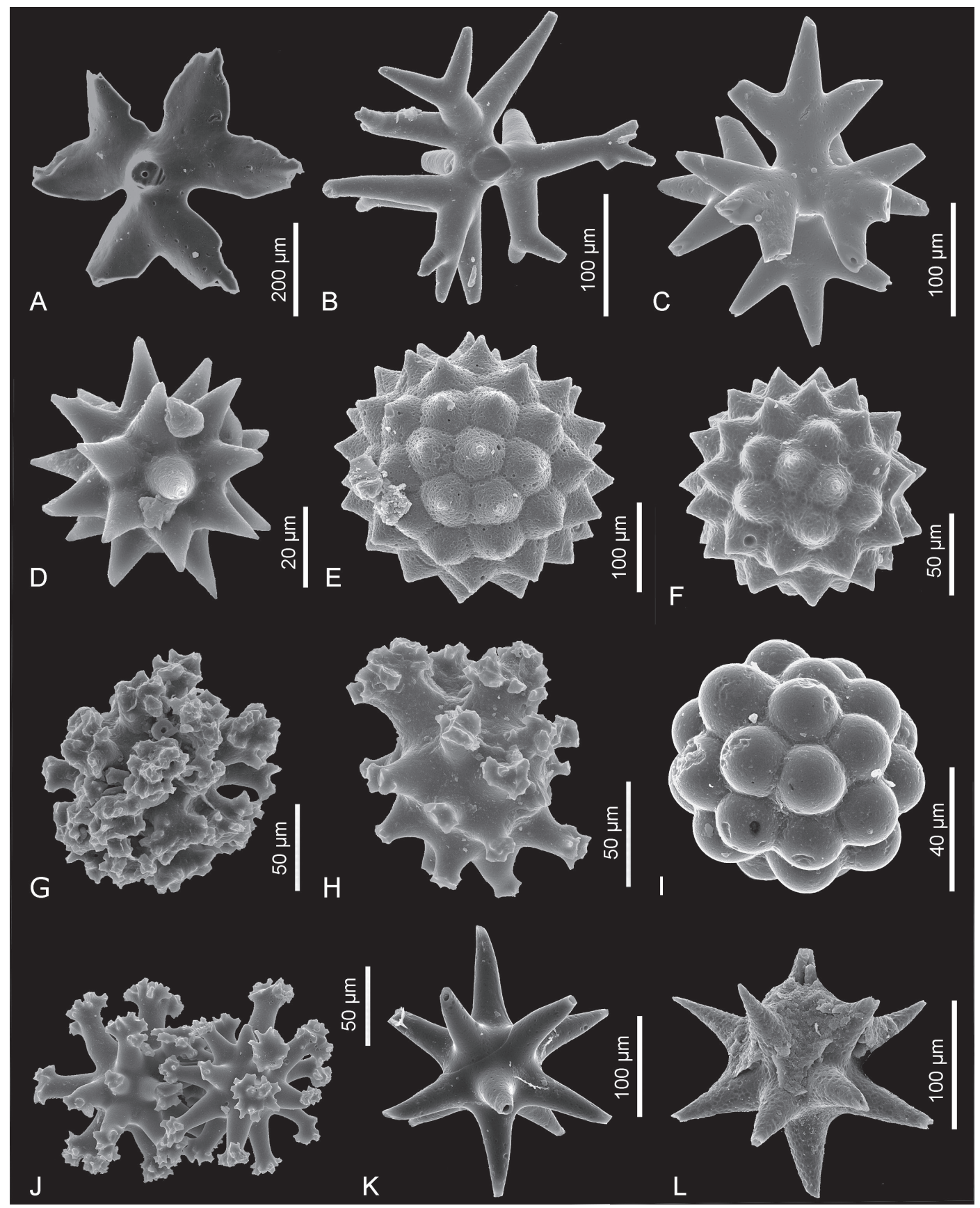

Fig. 1. A Triaene of Penares cf. sclerobesa; B Short-shafted triaene of Triptolemma cladosum; C Amphitriaene of Samus anonymus; D Spheraster of Chondrilla nucula; E-F Spherasters of Chondrilla secunda; G, H, J Anthasters of Diplastrella cf. megastellata; I Micraster of Tethya cf. omanensis; K, L Oxyasters of Tethyastra oxyaster (after Łukowiak, 2015, modified).

2003; Matteucci and Russo, 2005; Pisera et al., 2006; Łukowiak et al., 2014; Frisone et al., 2014). The fossil sponges from the Southern Hemisphere remained understudied. There are a few exceptions such as the de- tailed study by Hinde and Holmes (1892) on the isolated sponge spicules from the Eocene of Oamaru Diatomite (New Zealand). This study reconstructs the sponge assemblage and infers its bathymetry. Also, 
Kelly and Buckeridge (2005) interpreted Early Paleogene sponge fauna from the New Zealand Chatham Island in terms of the environmental conditions and water depth.

This approach - the biological interpretation of disassociated sponge spicules - was used to assess upper Eocene spongiolites and spiculites exposed along the southern coast of Australia. The reconstructed assemblage consisted of at least 42 species within 31 genera, 27 families, and 12 orders of 'soft' Demospongiae and Homoscleromorpha. Also, some lithistids and rare Hexactinellida were found in the assemblage. The spicules representing demosponge orders Poecilosclerida and Tetractinellida were the most diversified. The rest of the ten orders (Chondrillida, Haplosclerida, Axinellida, Bubarida, Agelasida, Polymastiida, Clionaida, Tethyida, Suberitida, and Homosclerophorida) were less differentiated (for more details see Łukowiak, 2015). The taxonomical assignments in this paper were updated basing on Morrow and Cárdenas (2015) new Demospongiae classification.

In this paper, the reconstructed assemblage is interpreted in a paleoecological and environmental context. Thanks to the comparisons with modern sponge communities of Australia, it was possible to establish the changes in the biota over the past 35 millions of years.

\section{Material and methods}

The samples were collected in April-May 2004 by Andrzej Pisera (with the exception of core samples, donated kindly by Paul Gammon, Canada). About 30 samples of spicule-rich clays, muddy spiculites, and spiculites were processed in the laboratory at the Institute of Paleobiology, Polish Academy of Sciences, Poland. The samples were macerated using Glauber's salt $\left(\mathrm{Na}_{2} \mathrm{SO}_{4}\right)$ or hydrogen peroxide $\left(\mathrm{H}_{2} \mathrm{O}_{2} 30 \%\right)$ to remove organic matter, and to clean and separate loose sponge spicules (see Łukowiak, 2015 for additional preparation details). All the investigated material is housed in the Institute of Paleobiology, Polish Academy of Sciences, Warsaw, Poland under the collection number ZPAL Pf.26.

\section{Geological context}

Upper Eocene strata with isolated sponge spicules (and bodily preserved sponges) extend over $2000 \mathrm{~km}$ along the southern coast of Australia, from Blanche Point in the east (St. Vincent Basin, eastern South Aus- tralia), through Norseman and Princess Royal in the north (western Eucla Basin and associated palaeodrainage channels), and Hamersley River and Doyle Road within the Fitzgerald River National Park in the west (Bremer Basin of Western Australia). These sites are characterized by different geological histories and facies development. In the late Eocene, Australia was in its final stages of separation from Antarctica, after which climatic cooling initiated due to inception of the Antarctic Circumpolar Current (for more details see Exton et al., 2001; Barker et al., 2007; Quaglio et al., 2007).

The megathermed to mesothermed climate of Australia, prior to the end of the Eocene was characterized in high climatic seasonality (McLoughlin and McNamara, 2001; Carpenter et al., 2014). Deep chemical weathering and the opal pulse that took place in the middle Eocene caused mobilization of silica and increased levels of silica in the oceans (Diekmann et al., 2004).

The studied sponge spicules were obtained from various upper Eocene units. Mainly muddy spiculites and spongiolites were sampled from Doyle Road, Princess Royal, and the Hamersley River glauconitic and spiculitic marls and limestones and biosiliceous clays were sampled at Blanche Point (for more details see Łukowiak, 2015).

\section{Results}

Short ecological characteristic and biogeographic distribution of the recognized sponge taxa

The diversity and excellent preservation of the siliceous sponge spicules witness the presence of a very rich sponge fauna in southern Australia waters during the late Eocene. It is estimated that at least nine orders, 27 families, 31 genera, and 42 species of 'soft' (including the sponges of the class Homoscleromorpha) demosponges inhabited this area. In addition to these, lithistids were also very common and rare sponges of the class Hexactinellida also appeared. The short tabular combination of the ecological preferences of the reconstructed sponge community and their current biogeographic distribution is shown in the Table 1. Also the most characteristic sponge spicules that were the basis for the taxonomical assignments of most of the sponge taxa are shown in the Figures 1-3. For more details see the chapter 'Biological interpretation of the morphological types of the 
Table 1. List of the recognized sponge taxa and the bathymetrical and ecological preferences of their recent counterparts. ALA - Atlas of Living Australia, WPD - World Porifera Database.

\begin{tabular}{|c|c|c|}
\hline & Bathymetry & Current geographical occurrence/range \\
\hline Agelasidae & $\begin{array}{l}\text { shallow-water reefs and other clear-water } \\
\text { environments in depths less than } 150 \mathrm{~m} \\
\text { (van Soest, 2002e) }\end{array}$ & \\
\hline Agelas axifera & & $\begin{array}{l}\text { W and E Australia (e.g. Champion Bay, Hooper } \\
\text { and Wiedenmayer, 1994; van Soest et al., 2012) }\end{array}$ \\
\hline Agelas wiedenmayeri & & Cuba (Alcolado, 1984) \\
\hline Pachastrellidae & \multicolumn{2}{|l|}{$\begin{array}{l}\text { epibathyal and bathyal habitats; few genera is } \\
\text { encrusting or cavity-filling living predominantly in } \\
\text { tropical or temperate shallow-waters (Maldonado, 2002) }\end{array}$} \\
\hline Triptolemma cladosum & $\sim 250 \mathrm{~m}$ (van Soest, 2009) & Indonesia (Maldonado, 2002) \\
\hline Brachiaster simplex & 200 m (Wilson, 1925; Lévi and Lévi, 1989) & $\begin{array}{l}\text { New Zealand, Philippines (WPD, accessed Feb } \\
\text { 2014), (fossil B. claudelevii is reported from } \\
\text { Australia; Pisera and Bitner, 2007) }\end{array}$ \\
\hline Alectona millari & $\begin{array}{l}\text { small excavating sponges living cryptically in } \\
\text { rather shallow depths (e.g. } 54 \mathrm{~m}, 202 \mathrm{~m} \text {; } \\
\text { Rützler, 2002a) }\end{array}$ & $\begin{array}{l}\text { Azores, Mediterranean Sea, North Sea, Alboran } \\
\text { Sea, Australia (WPD, accessed Feb 2014) }\end{array}$ \\
\hline Stelletta & $\begin{array}{l}\text { soft, detritic, and hard (rocky) bottoms from } \\
\text { shallow waters to bathyal depths (Uriz, 2002c) }\end{array}$ & $\begin{array}{l}\text { all over the world (Uriz, 2002c) including } 44 \\
\text { species from (ALA, accessed Feb 2014) }\end{array}$ \\
\hline Geodiidae & \multicolumn{2}{|c|}{$\begin{array}{l}\text { bathyal distribution predominantly on soft bottoms } \\
\text { (some representatives occur in caves and overhangs } \\
\text { in the littoral and shallow sublittoral zones; Uriz, 2002a) }\end{array}$} \\
\hline Geodia & & $\begin{array}{l}\text { distributed worldwide (Hooper and Wiedenmayer, } \\
\text { 1994), including } 4 \text { species from Australia (ALA, } \\
\text { accessed Feb 2014) }\end{array}$ \\
\hline Calthropellidae & $\begin{array}{l}\text { warm, moderately deep water }(\sim 600 \mathrm{~m}) \text { and } \\
\text { occasionally from the littoral zone (van Soest and } \\
\text { Hooper, 2002b) }\end{array}$ & $\begin{array}{l}\text { N Atlantic, Mediterranean, S and E Africa, } \\
\text { Indonesia, New Zealand (van Soest and Hooper, } \\
\text { 2002b), and Australia (ALA, accessed Feb 2014) }\end{array}$ \\
\hline Spirastrellidae & \multicolumn{2}{|l|}{$\begin{array}{l}\text { common in shaded subtropical and tropical shallow- } \\
\text { waters, including coral reefs (Rützler, 2002c) }\end{array}$} \\
\hline Diplastrella megastellata & shallow water (few feet; Hechtel, 1965) & $\begin{array}{l}\text { Caribbean (Hechtel, 1965) but Diplastrella sp. was } \\
\text { noted from Australia by McEnulty et al. (2011) }\end{array}$ \\
\hline Tethya omanensis & $\begin{array}{l}\text { very shallow waters of not more than } 5 \mathrm{~m} \\
\text { (van Soest and Beglinger, 2008) }\end{array}$ & $\begin{array}{l}\text { Oman and the W Arabian Sea (McEnnulty and } \\
\text { Beglinger, 2008) }\end{array}$ \\
\hline Tethyastra oxyaster & coral reefs (Burton, 1934) & $\begin{array}{l}\text { E Australia (Burton, 1934; WPD accessed Feb } \\
\text { 2013) }\end{array}$ \\
\hline
\end{tabular}

Placospongiidae

Placospongia

Cliona mucronata

Dotona pulchella

Sphaerotylus

Terpios encrusting or branching, massive sponges, mostly occur in shallow tropical and subtropical water habitats, from the intertidal depths to $\sim 200 \mathrm{~m}$ (Rützler, 2002b; Becking, 2013)

waters of about $20 \mathrm{~m}$ depth (Calcinai et al., 2005; Vacelet et al., 1976)

excavating, sampled from water of 70-120 m deep (Carter, 1880)

wide bathymetric range, e.g. S. antracticus is recorded from 18-385 m (Hentschel, 1914) growing as thin crusts on and under overhanging and dead corals in rather shallow waters (van Soest, 2002a)
2 species from Australia (WPD, accessed Feb 2014) Mexican Tropical Pacific, Madagascar (Vacelet and Vasseur, 1971; WPD, accessed Feb 2014), Indo-Pacific Ocean (Calcinai et al., 2005), Banada Sea (Topsent, 1897), Australia (ALA, accessed Feb 2014)

Mediterranean (Rosell and Uriz 2002) and probably Azores (Topsent, 1904) and the Indian Ocean (Carter, 1880)

2 species from Australia (ALA, accessed Feb 2014)

4 species from Australia (WPD, accessed Feb 2014) 
Table 1. Cont.

\begin{tabular}{|c|c|c|}
\hline & Bathymetry & Current geographical occurrence/range \\
\hline Monocrepidium eruca & $\begin{array}{l}\text { encrusting, surface hispid, deep water } \\
\text { (Alvarez and van Soest, 2002) }\end{array}$ & $\begin{array}{l}\text { Indian Ocean (Alvarez and van Soest, 2002; WPD, } \\
\text { accessed Feb 2014) }\end{array}$ \\
\hline Bubaris & $\begin{array}{l}\text { encrusting sponges with hispid surface that are } \\
\text { restricted to rather deep water (Alvarez and } \\
\text { van Soest, 2002) }\end{array}$ & $\begin{array}{l}\text { Arctic, Indian Ocean, S Atlantic, Mediterranean } \\
\text { Sea, Indonesia, Japan, New Zealand, and } \\
\text { Antarctica (Hooper and Wiedenmayer, 1994) }\end{array}$ \\
\hline Petrosia & $\begin{array}{l}\text { shallow and deeper warm-temperate to cold waters } \\
\text { (Desqueyroux-Faúndez and Valentine, 2002) }\end{array}$ & $\begin{array}{l}\text { widely distributed, including } 24 \text { species } \\
\text { from Australia (ALA, accessed Feb 2014) }\end{array}$ \\
\hline $\begin{array}{l}\text { Mycale (Rhaphidotheca) } \\
\text { loricata }\end{array}$ & waters $845 \mathrm{~m}$ deep (Topsent, 1896) & Azores (van Soest and Hajdu, 2002) \\
\hline Coelodischela massa & $\begin{array}{l}\text { from } 70 \mathrm{~m} \text { depth to relatively deep water } \\
(410-505 \mathrm{~m})\end{array}$ & $\begin{array}{l}\text { New Caledonia (Lévi and Lévi, 1983) and Cape } \\
\text { Verde Islands (van Soest, 1988) }\end{array}$ \\
\hline Trikentrion flabelliforme & $\begin{array}{l}\text { shallow water (3-83 m; Hooper and Wiedenmayer, } \\
\text { 1994), } 100 \text { m (McEnnulty et al., 2011) }\end{array}$ & Australia (WPD, ALA, accessed Feb 2014) \\
\hline Histodermella australis & $\begin{array}{l}\text { waters } \sim 130 \text { m deep (van Soest, 2002d; Bergquist } \\
\text { and Fromont, 1988) }\end{array}$ & $\begin{array}{l}\text { New Zealand (van Soest, 2002d; Bergquist and } \\
\text { Fromont, 1988) }\end{array}$ \\
\hline Acarnus & $\begin{array}{l}\text { shallow water of temperate and tropical seas } \\
\text { (Hooper, 2002a) }\end{array}$ & $\begin{array}{l}\text { genus known from all over the world including } 6 \\
\text { species from Australia (ALA, accessed Feb 2014) }\end{array}$ \\
\hline Sceptrintus richardi & rather deep water of 200-300 m (Topsent, 1898) & $\begin{array}{l}\text { Azores, Canaries, and Madeira (WPD, accessed } \\
\text { Feb 2014) }\end{array}$ \\
\hline Sigmosceptrella quadrilobata & $\begin{array}{l}\text { extremely shallow water of 2-3 m of depth } \\
\text { (Vacelet and Vasseur, 1971) }\end{array}$ & $\begin{array}{l}\text { Madagascar and Mauritius (WPD, accessed } \\
\text { Feb 2014) }\end{array}$ \\
\hline Discorhabdella incrustans & depth of about 180 m (van Soest, 2002c) & $\begin{array}{l}\text { New Zealand (Three Kings Island; van Soest, } \\
\text { 2002c) }\end{array}$ \\
\hline Crellastrina alecto & deep waters (600 m depth; van Soest, 2002b) & Azores (van Soest, 2002b) \\
\hline
\end{tabular}

Myxillidae

Samus anonymus

form excavations in coralline algae in shallow water up to $50 \mathrm{~m}$ deep (van Soest and Hooper, 2002a)

all over the world, including Australia (ALA, accessed Feb 2014)

almost cosmopolitan: Brazil, Caribbean,

Indian Ocean, Mediterranean, and Australia (van

Soest and Hooper, 2002a; WPD, accessed Feb

2014)

Chondrilla nucula

tropical and subtropical coastal waters (Boury-Esnault, 2002)

Atlantic, Mediterranean Sea, W and E Pacific, Indo-Malayan region, Indian Ocean, the Red Sea, and Caribbean (WPD, accessed March 2014); New Zealand (Ch. nucula sensu Schmidt 1862; for more details see Bergquist, 1968; p. 63), Australia (ALA, accessed Dec 2014)

Chondrilla secunda

2-40 m (Fromont et al., 2008)

Australia (WPD, ALA, accessed Feb 2014)

Placinolopha sarai

shallow water of $10 \mathrm{~m}$ of depth (Topsent, 1897)

E Philippines (WPD, accessed Feb 2014)

Placinolopha bedoti

Banda Sea and the Indonesian Exclusive Economic

Zone (WPD, accessed March 2014)

\begin{tabular}{ll}
\hline "lithistids" & $\begin{array}{l}\text { occur mostly in deep waters but shallow-waters } \\
\text { "lithistids" also occur (Pomponi et al., 2001; } \\
\text { Pisera and Lévi, 2002; Pisera and Vacelet, 2010) }\end{array}$ \\
\hline hexactinellids & $\begin{array}{l}\text { deep-water inhabitants; in some cases noted in the } \\
\text { extremely shallow-water habitats (Barthel and } \\
\text { Tendal, 1994; Leys et al., 2007) }\end{array}$
\end{tabular}

spicules-a comparison with living sponges' (Łukowiak, 2015).

Numerous recognized sponges currently inhabit the waters around Australia [e.g. Agelas cf. axifera
Hentschel, 1911, Tethyastra oxyaster (Burton, 1934), Cliona mucronata Sollas, 1878, Chondrilla secunda Lendenfeld, 1885, Trikentrion flabelliforme Hentschel, 1912 as well as Terpios, Stelletta, Acarnus, Petrosia, 


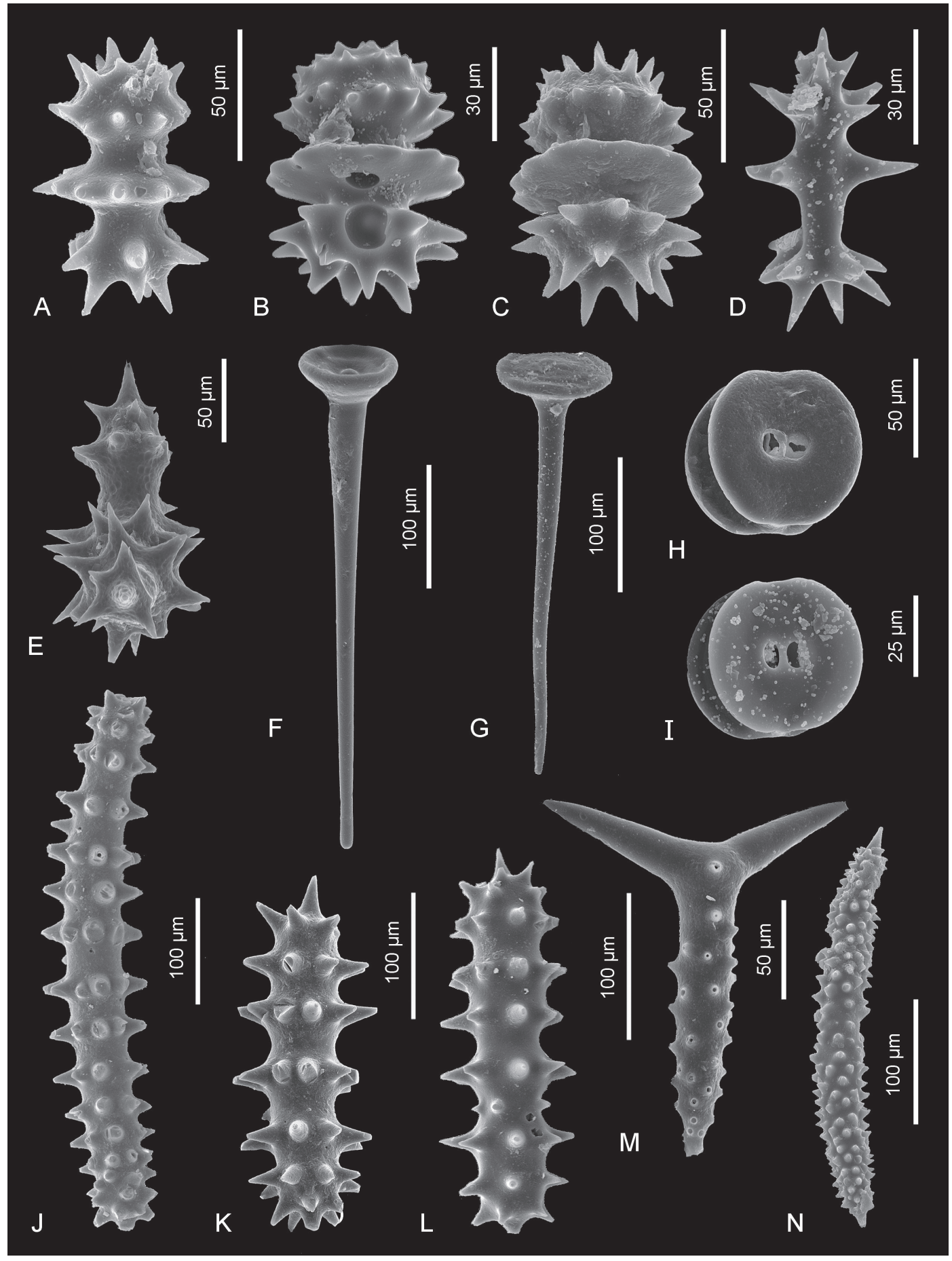

Fig. 2. A-D Anisodiscorhabds of Sigmosceptrella quadrilobata; E Pseudoastrose acanthotylote of Discorhabdella cf. incrustans; F Exotyle of Mycale (Rhaphidotheca) sp.; G Exotyle of M. (R.) cf. loricata; H, I Dischelae of Coelodischela cf. massa; J-L Sanidasters of Sceptrintus richardi; M Triod of Trikentrion flabelliforme; N Punctated oxea of Histodermella australis (after Łukowiak, 2015, modified). 


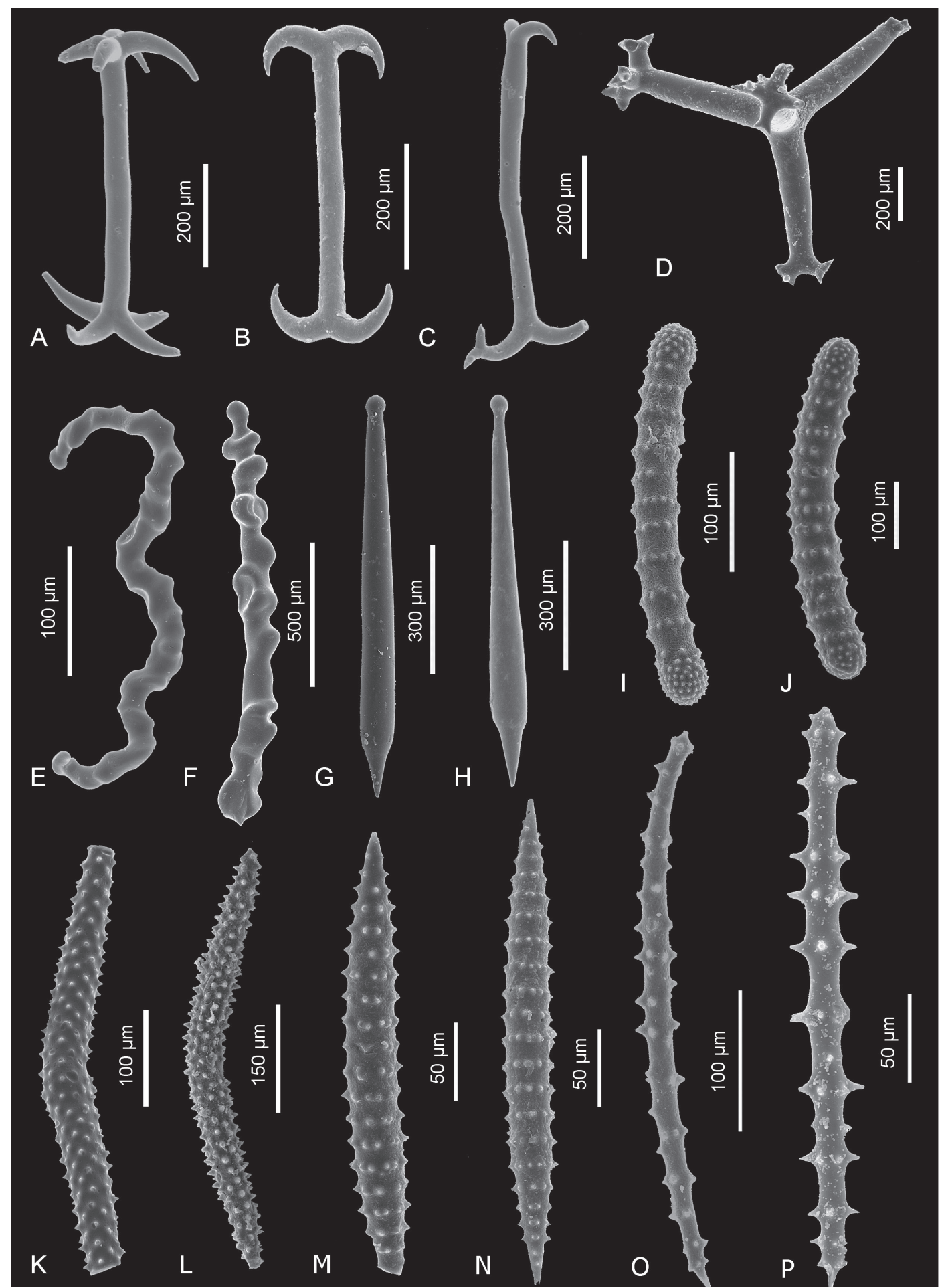

Fig. 3. A-C Amphiclads of Placinolopha cf. sarai; D Lophocalthrop of Placinolopha cf. bedoti; E Tuberculated diactine of Monocrepidium cf. eruca; F Tuberculated diactine of Bubaris sp.; G, H Mucronate tylostyles of Cliona cf. mucronata; I, J Verticillate strongyles of Dotona pulchella; K, L Acanthoxeas of Alectona millari; M, N Verticillate oxeas of Agelas cf. axifera; O, P Verticillate oxeas of Agelas cf. wiedemayeri (after Łukowiak, 2015, modified). 


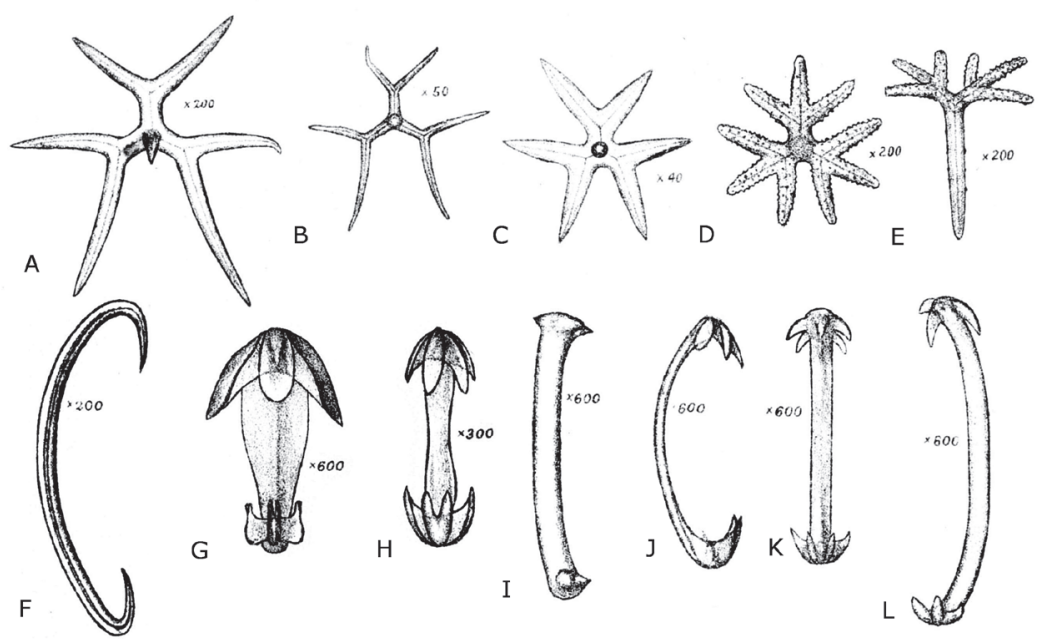

Fig. 4. Spicules of deep-water taxa: A-C Corallistes; D, E Thrombus abyssi; F, G Cladorhiza; H-L Chondrocladia; after Hinde and Holmes (1892; compiled).
Sphaerotylus, placospongiids, myxillids, and geodiids]. In the Eocene assemblage, there were some species that are today considered cosmopolitan morphospecies (e.g. Samus anonymus Gray, 1867, Chondrilla nucula Schmidt, 1862, and Alectona millari Carter, 1879) occurring also around Australia. There are also sponge taxa that are not currently observed in Australian waters but are noted from adjacent and nearby areas, e.g. New Caledonia (Coelodischela massa Lévi \& Lévi, 1983), New Zealand (Histodermella australis Dendy, 1924, Discorhabdella incrustans Dendy, 1924, Brachiaster sp., and Bubaris sp.), the Indian Ocean [Dotona pulchella Carter, 1880, Monocrepidium eruca (Carter, 1880)], and Indonesia [e.g. Triptolemma cladosum (Sollas, 1888), Placinolopha sarai Lévi \& Lévi, 1989, and Placinolopha bedoti Topsent, 1897]. In contrast, there is also a group of sponges that are today known only from geographically distant areas e.g. Arabian Pennisula (Tethya omanensis Sarà \& Bavestrello, 1995), Madagascar (Sigmosceptrella quadrilobata Dendy, 1922), Mediterranean (Dotona pulchella), or even the Caribbean (Agelas wiedenmayeri Alcolado, 1984, Diplastrella megastellata Hechtel, 1965) assuming the morphological characters reflect conspecificity. Other taxa occur today not only in remote parts of the world, e.g. Azores [Mycale (Rhaphidotheca) loricata (Topsent, 1896), Sceptrintus richardi Topsent, 1898, and Crellastrina sp.], but also are limited only to deep-water habitats (inhabiting waters of about $850 \mathrm{~m}, 200-300 \mathrm{~m}$, and $600 \mathrm{~m}$, respectively). Their bathymetrical preferences are in opposition to most of the recognized taxa which are shallow water inhabitants living in the continental platform (up to
200 m; e.g. Samus anonymus, Diplastrella megastellata, Alectona millari, Cliona mucronata, Dotona pulchella, Discorhabdella incrustans, Histodermella sp., Brachiaster sp., Terpios sp., Acarnus sp., agelasids, geodiids, placospongiids, and petrosiids). Moreover, some of them can be found in extremely shallow-water habitats (e.g. Tethyastra oxyaster, Tethya omanensis, Trikentrion flabelliforme, and chondrillids). From among moderately deep-water taxa (Sceptrintus, Sphaerotylus, Coelodischela massa and representatives of the family Plakinidae, pachastrellids, and bubarids) most are only occasionally found at shallow depths. Despite that, lithistid demosponges today are characteristic of rather deep waters (between 200 and $800 \mathrm{~m}$ ), some theonellid species occur also in shallow water (see Pomponi et al., 2001; Pisera and Lévi, 2002; Pisera and Vacelet, 2010; and the literature cited therein). Also hexactinellids which are currently deep-water forms in some cases may inhabit extremely shallow-water depths (Conway et al., 2001; Leys et al., 2004).

Comparison of Australian Eocene spicule assemblage with reinterpreted Eocene sponge spicules from the Oamaru Diatomite, New Zealand

The southern Australian late Eocene sponge fauna has never been fully and completely studied. However, the coeval sponge fauna from adjacent New Zealand was already described in the 19th century by Hinde and Holmes (1892). Numerous outcrops of upper Eocene-lower Oligocene strata of Oamaru Diatomite occur on the South Island, Otago, New Zealand. 
Table 2. Revised taxonomic assignment of the spicules described by Hinde and Holmes (1892) from the late Eocene-early Oligocene Oamaru Diatomite, South Island, New Zealand (with number of species) and sponge list noted from the late Eocene of southern Australia. * identified by Sim-Smith and Kelly (2011).

\begin{tabular}{|c|c|c|c|}
\hline Order & Family & New Zealand & Australia \\
\hline Chondrillida & Chondrillidae & & 2 Chondrilla \\
\hline \multirow{4}{*}{ Haplosclerida } & Chalinidae & ? Reniera now Haliclona (Reniera) & \\
\hline & & Schmidt, 1862, ? Chalina now & \\
\hline & & Haliclona (Reniera) Schmidt, 1862 & \\
\hline & Petrosiidae & & Petrosia \\
\hline \multirow[t]{2}{*}{ Axinellida } & Axinellidae & ? Axinella & \\
\hline & Raspailiidae & ? Hymeraphia & Trikentrion \\
\hline Bubarida & Bubaridae & & Bubaris, Monocrepidium \\
\hline \multirow{8}{*}{ Tetractinellida (Astrophorina) } & Ancorinidae & 6 Stelletta and/or Geodites & Stelletta \\
\hline & Calthropellidae & & Calthropella \\
\hline & Geodiidae & Geodia, 2 Erylus & 2 Geodia, 2 Penares \\
\hline & Pachastrellidae & 2 Pachastrella, Triptolemus now & \\
\hline & & Triptolemma de Laubenfels, 1955 & Triptolemma, Brachiaster \\
\hline & Thoosidae & Alectona, 2 Thoosa & Alectona \\
\hline & Thrombidae & Thrombus abyssi & \\
\hline & Astrophorida incertae sedis & $\begin{array}{l}\text { Dactylocalycites callodiscus, } \\
2 \text { undetermined }\end{array}$ & Dactylocalycites callodiscus \\
\hline Tetractinellida (Spirophorina) & Samidae & & Samus \\
\hline Agelasida & Agelasidae & & 3 Agelas \\
\hline Polymastiida & Polymastiidae & & 2 Sphaerotylus \\
\hline Merliida & Hamacanthidae & 3 Hamacantha & \\
\hline \multirow[t]{14}{*}{ Poecilosclerida } & Acarnidae & Acarnus, Iophon & Acarnus \\
\hline & Cladorhizidae & Cladorhiza, 4 Chondrocladia & \\
\hline & Crambeidae & Discorhabdella & Discorhabdella \\
\hline & Crellidae & & Crellastrina \\
\hline & Desmacididae & 6 Myxilla/6 Desmacidon & \\
\hline & Coelosphaeridae & 2 Forcepia & 2 Histodermella \\
\hline & Esperiopsidae & 4 Esperiopsis, Amphilectus & \\
\hline & Guitarridae & 2 Guitarra & Coelodischela \\
\hline & Hymedesmiidae & 4 Pseudohalichondria & \\
\hline & & 2 Plocamia now Antho Schmidt, 1870 & \\
\hline & Latrunculiidae & 14 Latrunculia & \\
\hline & Mycalidae & 10 Esperella now Mycale Gray, 1867 & 2 Mycale \\
\hline & Myxillidae & Melonanchora, 6 Myxilla/6 Desmacidon & Myxillidae \\
\hline & Podospongiidae & $\begin{array}{l}2 \text { Diacarnus }^{*}, \text { Sigmosceptrella } \\
\text { quadrilobata }\end{array}$ & 2 Sceptrintus, Sigmosceptrella \\
\hline \multirow[t]{3}{*}{ Clionaida } & Clionaidae & 2 Cliona described as Pronax & Cliona, Dotona \\
\hline & Spirastrellidae & 2 Spirastrella & 2 Diplastrella \\
\hline & Placospongiidae & & Placospongia \\
\hline Tethyida & Tethyidae & 2 Tethya & Tethya, Tethyastra \\
\hline \multirow[t]{2}{*}{ Suberitida } & Suberitidae & & Terpios \\
\hline & ?Halichondriidae & ? Hymeniacidon & ? Family Halichondriidae \\
\hline \multirow[t]{2}{*}{ Homosclerophorida } & Plakinidae & 4 Corticium, Plakina & 2 Placinolopha \\
\hline & Other & ? 2 Ditriaenella, 1 undetermined & \\
\hline \multirow[t]{4}{*}{ "lithistids" } & Pleromidae & Lyidium now Pleroma Sollas, 1888 & Pleroma \\
\hline & Vetulinidae & Vetulina & \\
\hline & Corallistidae & 2 Corallistes & Corallistidae \\
\hline & Theonellidae & $\begin{array}{l}2 \text { Discodermia } \\
\text { undetermined }\end{array}$ & $\begin{array}{l}\text { Discodermia, } \\
\text { Theonella/Racodiscula }\end{array}$ \\
\hline \multirow[t]{2}{*}{ Amphidiscosida } & Hyalonematidae & 5 Hyalonema & \\
\hline & Pheronematidae & Pheronema & \\
\hline Lyssacinosida & Rossellidae & Caulophacus, 2 Crateromorpha & Rossella \\
\hline Hexactinosida & Aphrocallistidae & 2 Aphrocallistes & Hexactinosida \\
\hline
\end{tabular}




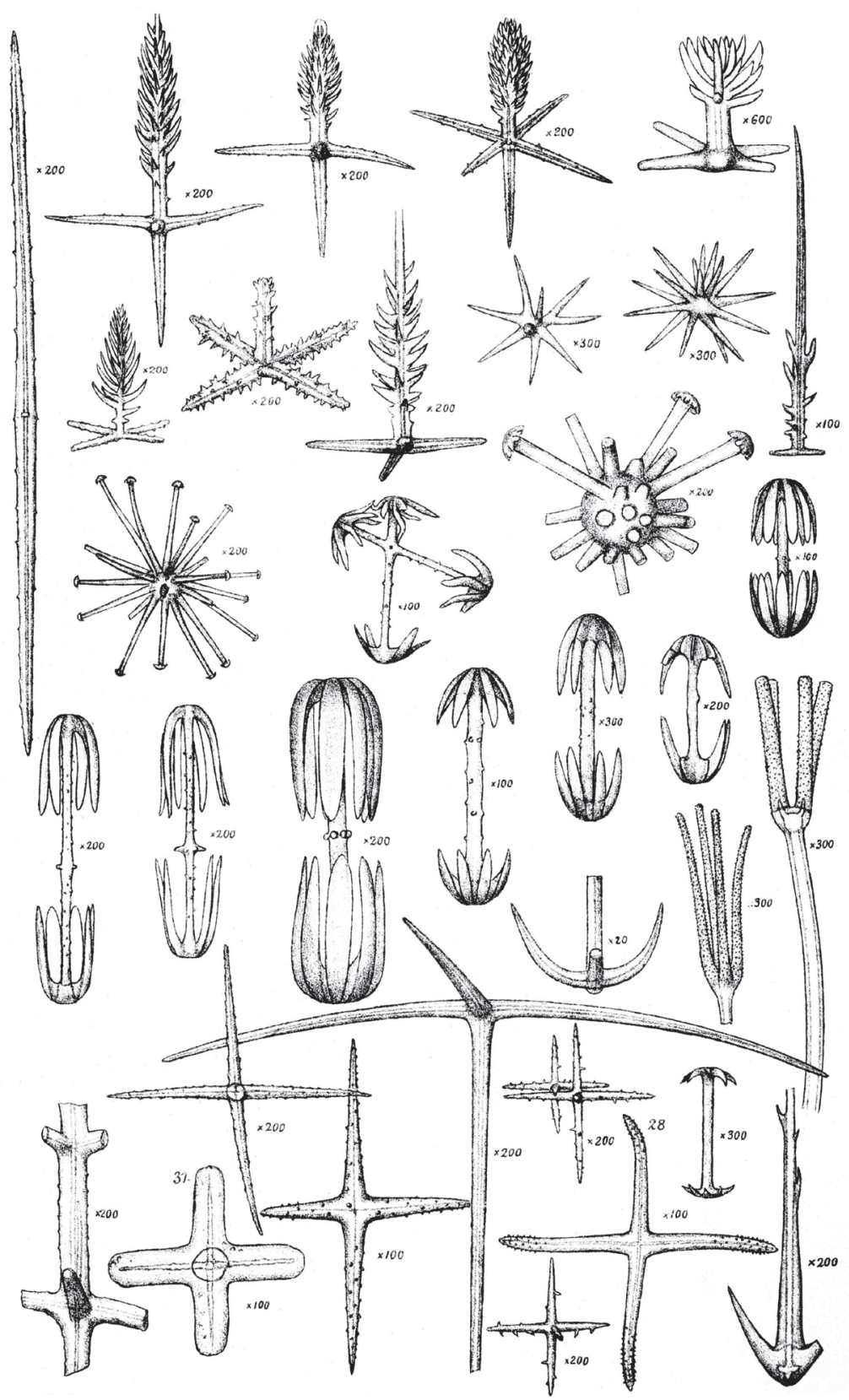

Fig. 5. Spicules of deep-water hexactinellids, after Hinde and Holmes (1892).

In these siliceous and siliceo-calcareous sediments the sponge spicules are, next to radiolarians and diatoms, the most common fossils. The great abundance of very well-preserved, abundant, isolated micro- and megascleres (and the lack of bodily preserved specimens) characterize this assemblage. The presented comparison (see Tab. 2) of the sponge spicules is done using modern taxonomy based on the World Porifera Database (accessed on August 2014; and supplemented with taxonomical assignments done by Sim-Smith and Kelly, 2011) reinterpreting attributions by Hinde and Holmes (1892).

The assemblage from the Oamaru region (New Zealand) is, in general, richer in spicule morphotypes. Especially the microscleres are more abundant and diverse than in the Australian association. This fact results in the recognition of higher number of sponge taxa in the assemblage described by Hinde 
and Holmes (1892). The Oamaru Diatomite sample records about twice as many non-lithistid demosponge species as in the Australian one, and a higher number of both lithistid and hexactinellid spicules as well. Whereas in the upper Eocene sediments of Australia only 42 'soft' sponge species have been recognized (classes Demospongiae and Homoscleromorpha), at least 91 species (and 11 uncertain or undetermined species) of siliceous 'soft' sponges were described in the Oamaru Diatomite. However, when considering the number of genera, the differences between these two sponge assemblages decrease. The Australian assemblage is slightly less diversified regarding the number of genera with 31 taxa described in contrast to 32 genera described from the New Zealand. Most demosponge families known from the Australia occur also in the New Zealand assemblage, but only 17 appear in both these assemblages at the same time (for details see Tab. 2).

The strictly shallow-water sponge taxa that were present in the Australian assemblage (e.g. Samus anonymus, Chondrilla nucula, Trikentrion flabelliforme, and Cliona mucronata; see also Figs 4, 5) were not recorded in the Oamaru. On the contrary, deep water astrophorid Thrombus abyssi (Carter, 1873) and poecilosclerids Cladorhiza and Chondrocladia (that are currently limited to deep water) are reported only form New Zealand. Also numerous hexactinellids (11 species) that are accesoric in the Australian assemblage appear in a great number in the New Zealand association. According to the lithistid demosponges, in the Oamaru Diatomite seven species were recognized, including deep-water Corallistes, whereas in the Australian assemblage only three families were noted.

It is worth mentioning that entirely preserved lithistids are very common and diversified in Australia, in contrast to Oamaru (Gammon et al., 2000a; Pisera personal information). However, the bodily preserved sponges do not deliver many loose spicules to the sediment, due to their complete preservation (non-destruction), and the record of loose lithistid spicules is, thus, sparse in Australian assemblage. But the rarity of hexactinellid spicules is real.

Comparison of the Australian late Eocene sponge assemblage with the extant demosponge fauna of southern Australia

The present-day sponge fauna of the World, its diversity, biogeographic, and bathymetric distribution, as well as its dynamics and interdependence is still poor- ly understood and studied. But comparing the sponges of Australia with those of other regions it is, next to the Mediterranean and Caribbean, one of the best-known sponge faunas (e.g. van Soest, 1994). However, it is estimated that still at least $60 \%$ of Australian sponges are undescribed (McDonald et al., 2005). There are approximately 1,400 species within 313 genera and 83 families of Australian sponges recorded (Hooper and Wiedenmayer, 1994) but about 5,000 species are estimated for the entire regional fauna (Hooper and Lévi, 1994). Recently, sponges of this region have received more attention (e.g. Munro et al., 1999) and there are large collections of marine sponges, as well as some independent groups of taxonomic researchers working primarily on the tropical and subtropical Australian sponge faunas (Hooper and Ekins, 2005).

The coasts of Australia are divided into 19 marine demersal bioregions (Hooper and Ekins, 2005). According to this biogeographical classification, the sites analysed in this paper belong to the South Western Region (samples taken from the western part of the southern coasts of Australia) and to the Gulf Province (samples taken from the eastern coasts of South Australia in Gulf St. Vincent, Hooper and Ekins, 2005).

Unfortunately, the studies of the present-day Porifera in Australia are focused mostly on the northern part of the Australian continent (for more details see Hooper and Ekins, 2005, fig. 6). Much less attention has been dedicated to sponges of the southern coast. There are only a few sponge collection sites in the South Western Province and temperate southwestern Western Australia seems to be the most poorly known of all Australian regions (Hooper and Lévi, 1994). There is a high number of endemic species recorded in this area, however, and it is told that the majority of 'native' marine fauna resides in the south (Poore, 1995). For example, a biological survey of the major benthic habitats of the south coast in the Fitzgerald Biosphere Reserve identified 102 different sponge taxa (Colman, 1997). The Gulf Province sampling sites seem to be more numerous and are one of the bestrecognized and studied areas of southern Australia (for more details see Hooper and Ekins, 2005).

There are some significant differences in taxonomic composition and species richness between the major Australian marine bioregions, however (e.g. Hooper and Lévi, 1994). Also at the smaller 'intra-regional' spatial scale frequently the sponges form spatially heterogeneous assemblages with patchy distributions, often with high numbers of species, are not found in adjacent communities (so-called 'apparent endemics', 
Table 3. The list of sponges recorded today from the Spencer Gulf (from Sorokin and Currie, 2009, modified), and sponges recognized in the Eocene Blanche Point Fm., Gulf St. Vincent, eastern part of South Australia.

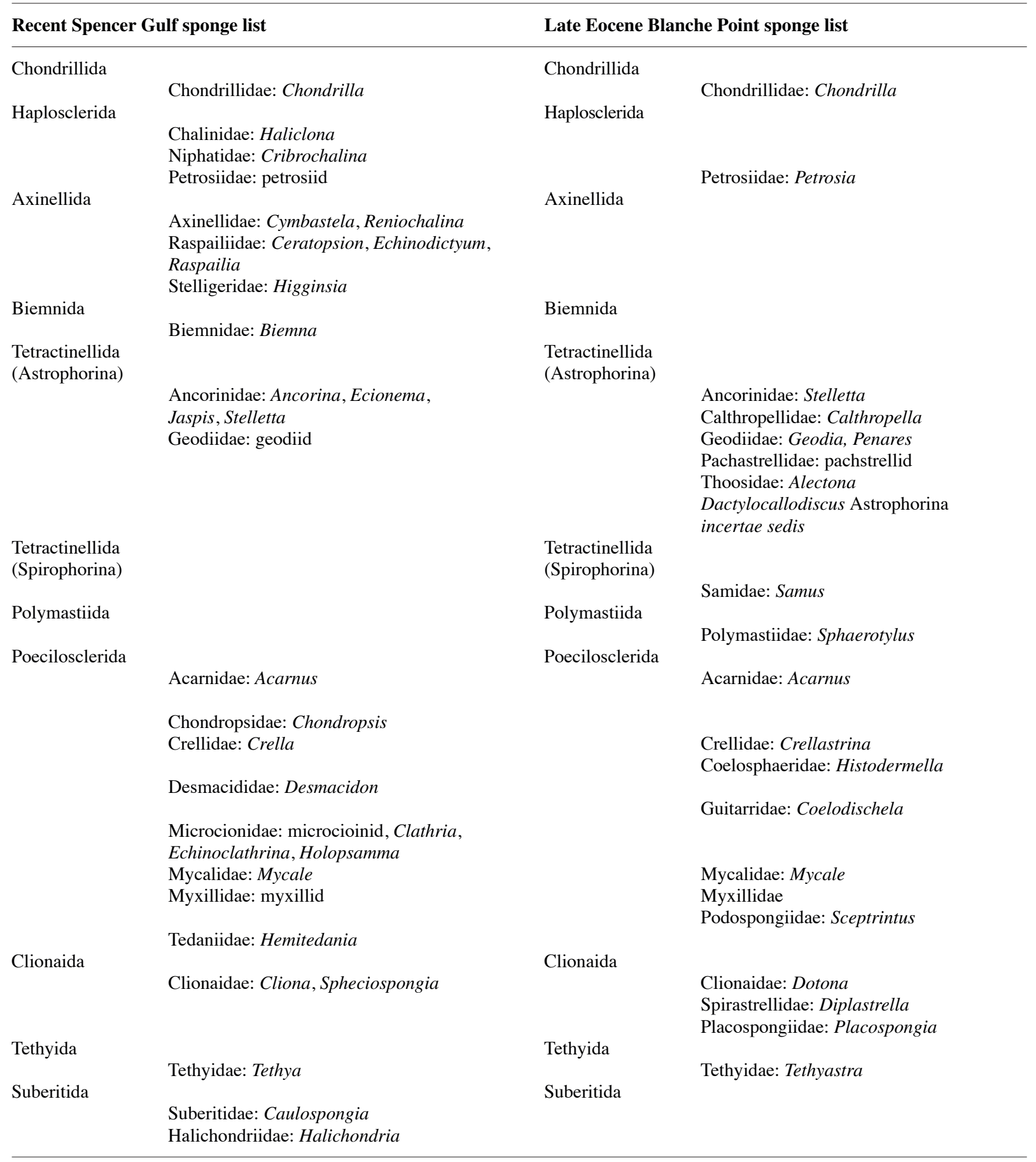

Hooper and Kennedy, 2002). This is the reason why these two provinces (South Western Province and Gulf Province) must be here treated separately.

In both the cases, orders Dictyoceratida, Dendroce- ratida, Verongiida, and haplosclerid family Callyspongiidae will be excluded from the analysis because sponges of these taxa do not produce a mineral skeleton and thus do not preserve in the fossil record. Additionally, in the 


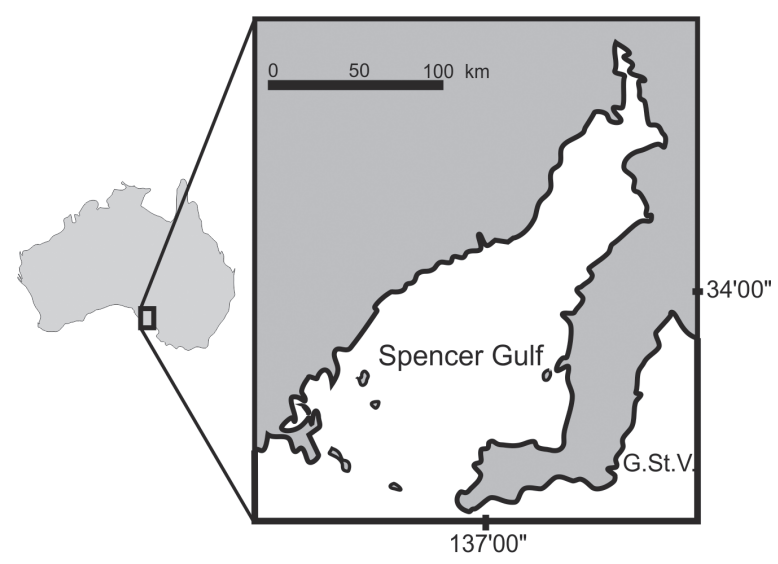

Fig. 6. Location of Spencer Gulf, South Australia; G. St. V.-Gulf St. Vincent.

case of the South Western Province, also the family Halisarcidae as one with a non-mineral skeleton will be excluded as well.

Gulf Province (Spencer Gulf) vs. Blanche Point Formation sponge fauna

As there are no complex elaborations of demosponge fauna from the Gulf St. Vincent (which could be the equivalent of the late Eocene Blanche Point sponge assemblage), the comparison of studied assemblage will be performed using the Spencer Gulf sponge list - the nearest, well-described area within the Gulf Province (Sorokin and Currie, 2009; Fig. 6).

In the Spencer Gulf, in the shallow-water depths ranging from 12 to $55 \mathrm{~m}$, there are ten orders, 22 families, and 28 genera of the class Demospongiae recognized. Among the 65 demosponge species present only 14 taxa could be given full species names (Sorokin and Currie, 2009; see also Tab. 3).

South Western Province vs. Western part of southern Australia Eocene sponge fauna

As there are no comprehensive elaborations of the Recent sponge fauna from the South Western Province (Fig. 7), the comparison of the late Eocene sponge assemblage of western part of south Australia will be done with the sponge list investigated in the Recherche Archipelago (Southwestern Region of Western Australia) - the closest geographically well-investigated area. The sponges of this region were reported from the depths of 0-25 m by McDonald, Kendrick, and Fromont (2005, SRFME Interim Final Report), and

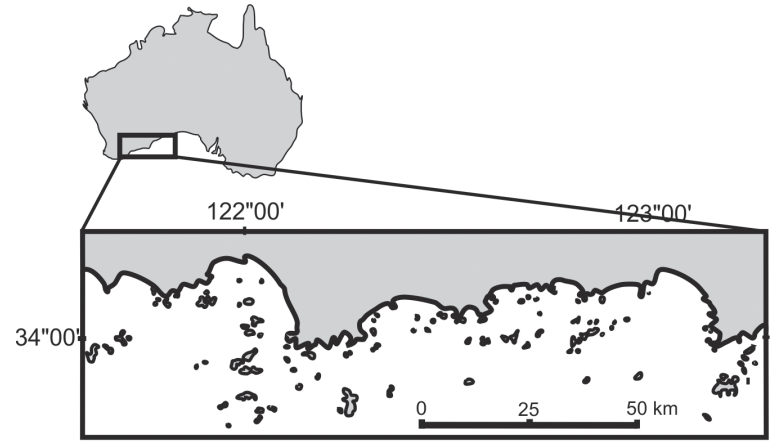

Fig. 7. Map of the Recherche Archipelago study sites, southern part of W Australia (after McDonald et al., 2005, modified).

kindly supplied by Jane Fromont (WAM, Perth). Additionally, this sponge list will be completed with the deeper-water sponge list (sampled in depths between 100-1100 m), reported from the Albany and Bald Island coasts which are also situated in the South Western Province (McEnnulty et al., 2011; see also Tab. 4). In the South Western Province there are 14 orders, 35 families, and 75 genera of the class Demospongiae recognized.

Whereas in the Recent assemblages of S Australia 37 families had been recognized, only 26 were recognized in the fossil one. From among these 37 families only 18 have their fossil representatives. On the other hand, nine other families were recognized in the fossil assemblage that are not recorded in this area in Recent. Regarding genera, today there are 77 recognized, whereas only 30 have been found in the fossil state. Among these, only 13 occur also in the fossil assemblage (e.g. Stelletta, Cliona, Geodia, Chondrilla, Terpios, Diplastrella, Tethya, Tethyastra, Petrosia, Mycale, Acarnus, Latrunculia and Agelas), which corresponds to about $16 \%$ of all the genera known in this area today.

Generally, considering the number of orders represented in the fossil and Recent assemblages, these two seem to be very similar (14 and 11 respectively). The only exceptions are the orders Biemnida, Desmacelli$\mathrm{da}$, and Trachycladida which were not recorded in Eocene of western part of southern Australia. The diversity at the family level, however, shows significant difference. In both discussed provinces only about half of families recognized have their representatives in the Eocene assemblage. On the other hand, some families (nine for Spencer Gulf Province and for South Western 
Table 4. List of extant sponges recorded from the Recherche Archipelago, South Western Australia (taken from McEnnulty et al., 2011 and McDonald et al., 2005, modified), and fossil sponges recognized in the southern part of W Australia.

Recent South Western Province sponge list Late Eocene W Australia sponge list

Chondrillida

Haplosclerida

Bubarida

Biemnida

Tetractinellida (Astrophorina)

Tetractinellida (Spirophorina)

Agelasida

Polymastiida

Desmacellida

Poecilosclerida

Clionaida

\section{Chondrillidae: Chondrilla}

Chalinidae: Haliclona

Niphatidae: Cribochalina, Gelliodes, Amphimedon

Petrosiidae: Neopetrosia, Petrosia, Xestospongia

Phloeodictyidae: Aka, Oceanapia, Tabulocalyx

Axinellidae: Axinella, Cymbastela, Dragmacidon,

Phakellia, Ptilocaulus, Reniochalina

Raspailiidae: Ceratopsion, Raspailia, Echinodictyum

Dictyonellidae: Dictyonella, Rhaphoxya, Acanthella

Biemnidae: Sigmaxinella, Biemna

Ancorinidae: Jaspis, Rhabdastrella, Stelletta, Asteropus, Ecionema, Ancorina, Psammastra

Geodiidae: Erylus, Geodia

Tetillidae: tetillid

Agelasidae: Agelas

Polymastiidae: Polymastia

Desmacellidae: Desmacella

Acarnidae: Acarnus

Chondropsidae: Chondropsis, Phoriospongia,

Psammoclema

Crambeidae: Monanchora

Crellidae: Crella, Anisocrella

Coelosphaeridae: Coelosphaera

Dendoricellidae: Pyloderma, Fibulia

Hymedesmiidae: Phorbas, Hymedesmia

Iotrochotidae: Iotrochopsamma, Iotrochota

Latrunculiidae: Latrunculia

Microcionidae: Antho, Clathria, Echinoclathria,

Holopsamma, Echinochalina

Mycalidae: Mycale

Tedaniidae: Hemitedania, Tedania, Strongylamma

Clionaidae: Cliona, Spheciospongia

Spirastrellidae: Diplastrella
Bubarida

Tetractinellida (Spirophorina)

Chondrillidae: Chondrilla

Haplosclerida

Petrosiidae: Petrosia

Axinellida

Raspailiidae: Trikentrion

Bubaridae: Bubaris, Monocrepidium

Biemnida

Tetractinellida

(Astrophorina)

Ancorinidae: Stelletta

Calthropellidae: calthropellid

Geodiidae: Geodia, Penares

Pachastrellidae: Triptolemma, Brachiaster

Thoosidae: Alectona

Samidae: Samus

Agelasida

Agelasidae: Agelas

Polymastiida

Polymastiidae: Sphaerotylus

Desmacellida

Poecilosclerida

Acarnidae: Acarnus

Crambeidae: Discorhabdella

Crellidae: Crellastrina

Coelosphaeridae: Histodermella

Guitarridae: Coelodischela

Latrunculiidae: Latrunculia,

Sigmosceptrella

Mycalidae: Mycale

Myxillidae: myxillid

Podospongiidae: Sceptrintus

Clionaida

Clionaidae: Cliona, Dotona

Spirastrellidae: Diplastrella

Placospongiidae: Placospongia 
Table 4. Cont.

\begin{tabular}{|c|c|c|c|}
\hline \multicolumn{2}{|c|}{ Recent South Western Province sponge list } & \multicolumn{2}{|c|}{ Late Eocene W Australia sponge list } \\
\hline Tethyida & & Tethyida & \\
\hline & $\begin{array}{l}\text { Tethyidae: Tethya, Xestospongia, Tethyastra } \\
\text { Hemiasterellidae: Hemiasterella }\end{array}$ & & Tethyidae: Tethyastra, Tethya \\
\hline Trachycladida & Trachycladidae: Trachycladus & Trachycladida & \\
\hline Suberitida & $\begin{array}{l}\text { Suberitidae: Protosuberites, Rhizaxinella, Caulos } \\
\text { Halichondriidae: Halichondria, Hymeniacidon } \\
\text { Styolocordylidae: Stylocordyla }\end{array}$ & $\begin{array}{l}\text { Suberitida } \\
\text { spongia }\end{array}$ & Suberitidae: suberitid \\
\hline Homoscleromorpha & & Homoscleromorpha & \\
\hline $\begin{array}{l}\text { lithistids } \\
\text { (undifferentiated) }\end{array}$ & homosclerophorid & lithistids & Plakinidae: Placinolopha \\
\hline
\end{tabular}

Province) do not currently occur in this area and are present only in the fossil assemblage. On the genus level, this disproportion seems to be even more significant because only $\sim 15 \%$ of genera in the Gulf Province and $\sim 14 \%$ of genera in the South Western Province have their fossil representatives.

\section{Discussion}

\section{Paleoecology and biogeography}

The inconsistence in bathymetric preferences among recognized sponge taxa - the dominance of shallowwater sponges with co-occurrence of lithistids, some hexactinellids, and two strictly deep-water demosponge taxa - has already been discussed by Gammon et al. $(2000 \mathrm{a}, \mathrm{b})$ who studied and interpreted the geology of the Paleogene of southern Australia. They proposed special environmental conditions e.g., the increased amount of nutrients, low light, calm hydrodynamics, and a high level of dissolved silica. These extraordinary conditions were caused by a specific paleogeographical setting and a high runoff from the thick regolith developed on the Australian continent which allowed the migration of deep-water lithistids as well as some hexactinellids into neritic depths during the Eocene.

The hypothesis of the shallow-water setting is also supported by the co-occurrence of rare other organisms, e.g. the diatom Arachnodiscus erhenbergii, which is currently known from temperate and tropical waters of mangrove-seagrass-algal communities (Round et al., 1990; Clarke, 1994). In the most western samples, the presence of rare zooxanthellate corals, which live in the photic zone, and ostracods indicating water depths of 50-100 m, also suggest moderately shallow water (James and Bone, 2000). Moreover, other abundant fossils, the coccoliths, gastropods, and ascidian sclerites, suggest the deposition of these sediments occurred in a relatively shallow and quiet sea floor environment below the wave base (Daily et al., 1976; James and Bone, 2000). This hypothesis is also supported by sedimentological data e.g. presence of an authigenic verdine mineral (odinite) which occurs in modern shallow tropical waters (of not more than 60 $\mathrm{m})$ and wave ripples that are characteristic for shallow water (for more details see e.g. James and Bone, 2000; Gammon et al., 2000a, b; McGowran and Alley, 2008).

The geographic range of some sponges has not changed since the late Eocene. But in some cases sponge taxa recognized in a fossil material were not found in the south Australian waters today. In the case of cryptic or excavating sponges there are two possible explanations of their current absence in Australia: 1) either these sponges have changed their geographical range since the late Eocene, or 2) their cryptic/excavating nature resulted in them being overlooked, and in fact, they occur today around Australia. This second possibility, in my opinion, seems to be more plausible as it is postulated in the latest studies (see e.g. Łukowiak et al., 2013). Currently, some among the recognized sponge taxa inhabit deep waters of geographically distant regions, during the late Eocene, however, they seem to have lived in shallow-water habitats. This suggests a shift in their bathymetrical preferences since the Eocene. Also, the present occurrence of some of the recognized taxa in the zone ranging from the North 
Atlantic to Indian Ocean and their absence in Australian waters is intriguing. It may be caused by different paleogeography in the Eocene. At that time, i.e., about 34 mya, the ancient equatorial sea called the Tethyan Ocean still existed. Tethys separated the southern continent (Gondwana) from the northern one (Laurasia). This sea, which formed during the Early Cretaceous (Wiedenmayer, 1994), was the dominating marine seaway extending far north-east. In terms of its extent, it is an equivalent of the major Recent oceans (NW and $\mathrm{N}$ Indian Ocean, Mediterranean, and the N Atlantic) with the Gibraltar Passage being opened. When the closure of the connection with the Indo-Pacific Ocean took place during the Early Miocene period, some of the Tethyan sponge taxa (the ones with wide longitudinal distribution in the Eocene) may have survived only in some refuges, i.e., the E Atlantic, Mediterranean, and the Arabian Sea. This part of the Tethys was closed (along the Zagos Crush Zone in the Middle East) only during the Oligocene, leaving a shallow seaway between the Eastern Mediterranean and the Gulf of Oman (Wiedenmayer, 1994). In the Miocene the Mediterranean was closed in the east (during the Tortonian) and in the west (during the Messinian). The closure provoked a Messinian salinity crisis which devastated marine faunas (Cita, 1984; Braga et al., 2006). In a result of such paleogeographic changes, the once continuous populations of the Tethyan sponges became separated and either went extinct, or differentiated/changed their habitats surviving as relict forms. Examples of such taxa that were widespread during the Eocene (even if not reported from other parts of the world, although it likely results from nonpreservation/lack of studies) seem to be Mycale (Rhaphidotheca) loricata, Sceptrintus richardi, and Crellastrina sp. These taxa currently only inhabit the deep waters around the Azores. Tethya cf. omanensis is known only from the Arabian Sea. Another example of a sponge with wider Cenozoic distribution is the crambeid Discorhabdella hindei Boury-Esnault, Pansini and Uriz, 1992. It occurs in the Mediterranean Sea (Alboran Sea) and reveals more similarities to the distant New Zealand species Discorhabdella incrustans than to other species of this genus known from the Azores (D. tuberosocapitatum; Boury-Esnault et al., 1992). In some cases, the recent distribution pattern of some sponge taxa (e.g. Alectona millari, Samus anonymus, and Dotona pulchella) overlaps (at least to some degree) with the former range of the Tethys. The Tethyan relicts have also been discovered among other animal taxa, e.g. gastropods and brachiopods (Zezina,
2009), echinoderms (Ozawa et al., 2009), and ostracods and foraminifers (Benson, 1976). On the other hand, it is worth noting that the molecular studies of such widely-distributed Recent sponge taxa show that they are often molecularly distinct evolutionary lineages (i.e., Chondrilla caribensis vs. Chondrilla nucula; Rützler et al., 2007), although very similar morphologically. Thus, they are lumped together into one cosmopolitan morphospecies (Klautau et al., 1999; Wörheide et al., 2002). Such morphospecies may consist, in fact, of several cryptic sibling species with high genetic diversity (that is not clearly manifested at the morphological level across their wide geographic ranges; e.g. Wörheide et al., 2002; Xavier et al., 2010 and the literature cited therein). This problem, however, is impossible to solve with the fossil material.

\section{Comparison with Oamaru Diatomite sponge fauna}

The diatomites of Oamaru, New Zealand, described by Hinde and Holmes (1892) are considered to have been deposited at considerable depths. Although Hinde and Holmes (1892) interpreted this sponge assemblage as indicative of water depth not less than $c a$ $1000-1500$ fathoms $(1800-2700 \mathrm{~m})$, it is more likely that these sponge communities inhabited waters of lesser depth. On the other hand, Edwards (1991) suggests these sediments to be deposited rather between 75 and $150 \mathrm{~m}$. The presence of a high number of strictly deep-water sponge taxa, as well as the lack of typically shallow-water sponges in these upper Eocene sediments, place the factual bathymetry of these sediments somewhere in-between these two hypotheses as postulated by Kelly and Buckeridge (2005). They established the water depth as being 500 to $800 \mathrm{~m}$, similar to that of Chatham Rise (east of New Zealand), which is characterised by a similar combination of demosponges, lithistids, and hexactinellids.

In the Oamaru, there are numerous hexactinellids (e.g. Hyalonema, Monorhaphis, Caulophacus) that belong to Amphidiscophora and are typical for very deep environments. Likewise, the occurrence of deepwater poecilosclerids (e.g. Cladorhiza, Esperiopsis, and Chondrocladia), which are reported currently from the bathyal zone, as well as the presence of the deep-water astrophorid Thrombus abyssi, support this supposition. However, it must be remembered that the Oamaru Diatomite assemblage also consists of some extremely shallow-water sponges (e.g. Myxilla). This admixture of shallow-water forms may be explained by their transport from surrounding areas. 
The studied Australian community is characteristic of a shallower depth. Such an interpretation is supported by the fact that hexactinellid spicules are rare in Australia, in contrast to New Zealand. Moreover, there are numerous shallow-water non-lithistid demosponge taxa (e.g. Sceptrintus richardi, Samus anonymus, Diplastrella megastellata, Cliona mucronata, Placospongia, and the chondrillids) that are absent in the New Zealand association.

In contrast to Oamaru, Australian lithistids (families Pleromidae, Corallistidae, and Theonellidae), are mostly known from entirely preserved individuals. They are extremely common and diversified but they delivered only sparse loose spicules. Worldwide, theonellids occur both in shallow and deep waters, while pleromids are found in considerable depths of about $600 \mathrm{~m}$. The same is true for Corallistidae (Pisera and Lévi, 2002). On the other hand, the lithistid family Vetulinidae, which is known from the Caribbean (Barbados) from the depth of 126-600 m, was recorded only in the New Zealand assemblage (Pisera and Lévi, 2002).

\section{Differences and similarities between Recent and fossil sponge faunas of Australia}

The lack of some sponge families in the fossil record can be explained by data loss during the process of fossilization, as well as the difficulties with the systematic assignment of the studied spicules (because of their simple, non-characteristic morphology). However, the presence of a higher number of sponge taxa in the Eocene assemblage is difficult to explain. It can result from 1) the poor study of the area (the sampling bias), and overlooking, especially small, cryptic, excavating or encrusting taxa, 2) the real changes in the taxonomic diversity of demosponges since the late Eocene. Indeed, some of the studied taxa that have no Recent representatives in the waters surrounding the south of Australia, such as thoosids and spirophorids, are excavating and cryptic, respectively. Placospongiids, on the other hand, are sometimes encrusting, while the spirastrellids are noted to be limestone-excavating and encrusting. Most probably, the mode of life of the above-mentioned taxa caused that they are not reported (overlooked) from Australia and actually may live in this area. Their presence may be confirmed after more careful studies. On the other hand, the lack of the representatives of the families Pachastrellidae, Guitarridae, and Coelosphaeridae (that are present in the fossil assemblage) in these waters today is difficult to understand. It seems that the only reasonable explanation is that these sponge taxa have changed their geographic range due to post-Eocene climate changes.

The current absence of the families Polymastiidae and Spirastrellidae in the Spencer Gulf may be only a matter of sampling bias because representatives of these families are today reported from adjacent area, e.g., the coasts of Coorong National Park, about 150 $\mathrm{km}$ north of Adelaide [Atlas of living Australia (ALA), accessed on August 2013]. This may be the case as the patchy sponge distribution at the 'intra-regional' spatial scale occurs with sometimes as little as $15 \%$ similarity in the species composition between geographically adjacent reef sites (Hooper, 1998).

On the other side, the apparent lack of the Axinellidae and Dendoricellidae in the fossil material may be explained by the fact that the sponges belonging to these families possess rather morphologically simple spicules which are difficult to assign to a particular family. The same is true for the order Haplosclerida whose members also usually produce such simple spicules. The absence of the poecilosclerid families Microcionidae, Desmacididae, Chondropsidae, and Tedaniidae is more questionable. These sponges usually bear very characteristic spicule morphotypes that are easy to distinguish. Most likely, their absence in the fossil material is factual rather than an effect of misinterpretation, overlooking or removal.

The lack of representatives of some demosponge families in the South Western Province, e.g. thoosids, and their presence in the fossil assemblage, may be explained by their ecology. Thoosidae are usually small limestone-excavating sponges that live in burrows made in calcareous algae, scleractinian corals, or octocorals. Thus, it is very easy to overlook them. Similarly, the sponges from the poecilosclerid family Crambeidae (e.g. Discorhabdella) are thinly encrusting animals (van Soest, 2002c). For this reason, their overlooking in general faunistic studies, which are often performed by dredging, would not be surprising as well. This applies for placospongiid and samid sponges, too. On the contrary, the apparent absence of families Axinellidae, Halichondriidae, Dictyonellidae Chalinidae, Niphatidae, and Phloeodictyidae in the fossil material is likely an artefact of "nondetermination' due to the uncharacteristic spicule morphotypes (mainly simple styles and oxeas, rarely some microscleres). These types of spicules occur in a wide range of demosponge families and thus are useless for distinguishing various taxa. For this reason, it is important to remember that their absence in the Eocene samples is most probably artificial. 
Nowadays, the poecilosclerids Sigmosceptrella quadrilobata and Sceptrintus richardi may really be absent in Australian waters as none of these species are recorded from this area (ALA, accessed on Aug 2014). Also, the families Tedaniidae, Hymedesmiidae, and Dendoricellidae recognized currently in the southern Australia are absent in fossil material. They have rather characteristic, and easy to recognize and distinguish spicules, (e.g. onychaetes, subtylostyles, acanthostyles, toxas, and isochelae) which really suggest a change in their biogeographic distribution since the late Eocene. The apparent absence of the family Hemiasterellidae in the fossil material, which also has rather characteristic astrose spicules, may not be real because the spicules of hemiasterellids are similar to the oxyasters of Astrophorina. Therefore, they might have been misassigned.

It seems that the only real difference between the Eocene and Recent sponge fauna is the absence of families Microcionidae, Dendoricellidae, Desmacididae, Chondropsidae, Tedaniidae, Hymedesmiidae, Iotrochotidae, Stylocordylidae, and Trachycladidae in the fossil assemblage. Also, it appears to be probable that some astrophorines (families Calthropellidae and Pachastrellidae), poecilosclerids (families Guitarridae and Coelosphaeridae), and family Bubaridae in today's waters are absent, contrary to the Eocene fauna. The rest of the changes (the lack of taxa that are excavating or boring in habitus in Recent southern Australian waters, as well as taxa with simple spicule morphology in the fossil assemblage) do not seem to be factual. Rather, it was caused by various biasing factors that could have influenced the estimations of diversity.

The absence of rather deep-water inhabitants, lithistids, and hexactinellids in the Recent fauna, that occur in the fossil assemblage, may also be explained by the fact that most of them could have had different (shallower) bathymetrical ranges during the Eocene. These might be due to the conditions that allowed them to inhabit shallow water, i.e., high silica level. Also more favourable water temperatures in that time might have made shallow water more attractive habitat to live (Exton et al., 2001; Quaglio et al., 2007) as the temperature may be one of the factors that drives faunal changes (Carballo et al., 2008 and the literature cited therein).

On the other hand, the current presence of various poecilosclerids and hadromerids around Australia, that are absent in the Eocene fauna, suggests the actual changes in the taxonomical composition.

\section{Conclusions}

Based on sponge composition, the rare non-sponge micro- and macrofauna, as well as published geological data, the 'soft' sponge assemblage of the late Eocene of southern Australian is interpreted as inhabiting silica-rich, shallow coastal water of about 100 meters of depth.

This interpretation is also supported by the comparison of the Australian fossil assemblage with similar but deeper-water Eocene spicule material from the Oamaru Diatomite, New Zealand. This assumption is based on the presence in Oamaru site of numerous sponge taxa (both, amphidiscophoran hexactinellids and non-lithistid demosponges) that are typical for deep waters of at least few hundreds of meters. The absence of shallow-water demosponges (that are present in Australia) support it as well.

As it shows the distribution pattern of the recognized sponge taxa, the studied assemblage has a clear Tethyan affinity. Some studied sponge taxa today inhabit the areas that are congruent with the range of the Tethys in the past. Also, the recent occurrence of some other fossil sponge taxa only in distant geographic regions and oceans is interpreted as a relic of such Tethyan distribution. It also proves that in geological past some sponge taxa had a wider geographic distribution and that they have survived to the present only in refugia.

The comparison of the studied late Eocene sponge fauna with the sponge communities inhabiting southern Australian waters today demonstrates a great similarity at the order level. The differences between both assemblages are more pronounced at lower levels (family, genus), with only about half of the Recent sponge families from Australia present in the Eocene assemblage. However, considering all difficulties that have played a role in the process of recognition, assignment, and comparison of fossil sponges with their Recent counterparts, there is no dramatic change in 'soft' sponge fauna composition in this area since the Eocene.

\section{Acknowledgements}

This text is a part of $\mathrm{PhD}$ dissertation made in the Institute of Paleobiology, Polish Academy of Sciences, under the supervision of Andrzej Pisera. I would like to thank Paul Gammon (Geological Survey of Canada) for donating and Andrzej Pisera (Institute of Paleobiology, Polish Academy of Sciences, Warsaw) for collecting the samples with support of KBN Grant 
number 3PO4D03924. I am also in debt to all people who contributed in my thesis in various ways. To Robert van Soest (Naturalis Biodiversity Center, Netherlands) and Michelle Kelly (NIWA, New Zealand) who helped with taxonomical assignment of some sponge spicules and Jane Fromont (Western Australian Museum, Perth) who kindly provided unpublished data on living Australian sponges. I wish also to thank Cyprian Kulicki for his help with the SEM analyses and Żaneta Bartosińska for her help in finding some literature (both Institute of Paleobiology, Warsaw), as well as Andrzej Pisera (Institute of Paleobiology, Polish Academy of Sciences, Warsaw) and Daniel Madzia (Institute of Paleobiology, Polish Academy of Sciences, Warsaw) for correcting linguistically the text. I am also deeply indebted to Stephen McLoughlin for his valuable corrections and suggestions. My special thanks are to my supervisor, Andrzej Pisera (Institute of Paleobiology) for his help and support during my entire $\mathrm{PhD}$ studies and the preparation of this manuscript. I am also indebted to the reviewers for their helpful suggestions that helped to considerably improve this manuscript.

\section{References}

Alcolado PM. 1984. Nuevas especies de esponjas encontradas en Cuba [New species of sponges from Cuba]. Poeyana 271: 1-22. (in Spanish)

Alvarez B, van Soest RWM. 2002. Family Bubaridae Topsent, 1894. Pp. 748-754 in: Hooper JNA, van Soest RWM, eds, Systema Porifera: a guide to the classification of sponges. New York, Boston, Dordrecht, London, Moscow: Kluwer Academic/ Plenum Publishers.

Antcliffe JB, Callow RHT, Brasier MD. 2014. Giving the early fossil record of sponges a squeeze. Biological Reviews 89: 972-1004.

Barker PF, Filippelli GM, Florindo F, Martin EE, Scher HD. 2007. Onset and role of the Antarctic Circumpolar Current. Deep Sea Research II 54: 2388-2398.

Barthel D, Tendal OS. 1994. Antarctic Hexactinellida. Synopsis of the Antarctic Benthos 6: 1-154.

Becking L. 2013. Revision of the genus Placospongia (Porifera, Demospongiae, Hadromerida, Placospongiidae) in the IndoWest Pacific. ZooKeys 298: 39-76.

Benson RH. 1976. Changes in the Ostracods of the Mediterranean with the Messinian salinity crisis. Palaeogeography, Palaeoclimatology, Palaeoecology 20: 147-170.

Bergquist PR. 1968. The marine fauna of New Zealand: Porifera, Demospongiae, Part 1. (Tetractinomorpha and Lithistida). New Zealand Department of Scientific and Industrial Research Bulletin [New Zealand Oceanographic Institute Memoir 37] 188: 1-105.

Bergquist P, Fromont J. 1988. The marine fauna of New Zealand: Porifera, Demospongiae, Part 4 (Poecilosclerida). New Zealand Oceanographic Institute Memoir 96: 1-197.

Boury-Esnault N. 2002. Order Chondrosida Boury-Esnault \& Lopes, 1985. Family Chondrillidae Gray, 1872. Pp. 291-298 in: Hooper JNA, van Soest RWM, eds, Systema Porifera: a guide to the classification of sponges. New York, Boston, Dordrecht, London, Moscow: Kluwer Academic/ Plenum Publishers.
Boury-Esnault N, Pansini M, Uriz MJ. 1992. A new Discorhabdella (Porifera, Demospongiae), a new Tethyan relict of preMessinian biota? Journal of Natural History 26: 1-7.

Braga JC, Martín JM, Riding R, Aguirre J, Sanchez-Almazo IM, Dinares-Turell J. 2006. Testing models for the Messinian salinity crisis: the Messinian record in Almería, SE Spain. Sedimentary Geology 188-189: 131-154.

Brasier MD. 1989. China and the palaeotethyan belt (India, Pakistan, Iran, Kazakhstan, and Mongolia). Pp. 40-74 in: Cowie JW, Brasier MD, eds, Precambrian-Cambrian Boundary. Oxford: Caleron Press.

Burton M. 1934. Sponges. Scientific Reports of the Great Barrier Reef Expedition 1928-29 4: 513-621.

Calcinai B, Bavestrello G, Cerrano C. 2005. Excavating sponge species from the Indo-Pacific Ocean. Zoological Studies 44: 5-18.

Carballo JL, Vega C, Cruz-Barraza JA, Yáñez B, Nava H, Ávila E, Wilson M. 2008. Short- and long-term patterns of sponge diversity on a rocky tropical coast: evidence of large-scale structuring factors. Marine Ecology 29: 216-236.

Carpenter RJ, McLoughlin S, Hill RS, McNamara KJ, Jordan GJ. 2014. Early evidence of xeromorphy in angiosperms: stomatal encryption in a new Eocene species of Banksia (Proteaceae) from Western Australia. American Journal of Botany 109: 1486-1497.

Carter HJ. 1873. On two new species of Gummineae, with special and general observations. Annals and Magazine of Natural History 12: 17-30.

Carter HJ. 1879. On a new species of excavating sponge (Alectona millari); and on a new species of Rhaphidotheca ( $R$. affinis). Journal of the Royal Microscopical Society 2: 493499.

Carter HJ. 1880. Report on specimens dredged up from the Gulf of Manaar and presented to the Liverpool Free Museum by Capt. W.H. Cawne Warren. Annals and Magazine of Natural History 6: 35-61, 129-156.

Cita MB. 1984. The Mediterranean Messinian. Bollettino Della Società Paleontologica Italiana 22: 185.

Clarke JD. 1994. Evolution of the Lefroy and Cowan palaeondrainage channels, Western Australia. Australian Journal of Earth Sciences 41: 55-68.

Colman JG. 1997. Biological survey of the major benthic habitats of the south coast. Starvation boat harbour - Groper Bluff, 7-21.

Conway KW, Krautter M, Barrie JV, Neuweiller M. 2001. Hexactinellid sponge reefs on the Canadian continental shelf: a unique 'living fossil'. Geoscience Canada 28: 71-78.

Daily B, Firman JB, Forbes BG, Lindsay JM. 1976. Geology. Pp. 5-42 in: Twidale CR, Tyler MJ, Webb BP, eds, Natural History of the Adelaide Region. Royal Society of South Australia.

Dendy A. 1922. Report on the Sigmatotetraxonida collected by H.M.S.'Sealark' in the Indian Ocean. Pp. 1-164 in: Reports of the Percy Sladen Trust Expedition to the Indian Ocean in 1905, Volume 7. Transactions of the Linnean Society of London 18.

Dendy A. 1924. Porifera. Part I. Non-Antarctic sponges. Natural History Report. British Antarctic (Terra Nova) Expedition, 1910 (Zoology) 6: 269-392.

Desqueyroux-Faúndez R, Valentine C. 2002. Family Petrosiidae van Soest, 1980. Pp. 906-917 in: Hooper JNA, van Soest 
RWM, eds, Systema Porifera: a guide to the classification of sponges. New York, Boston, Dordrecht, London, Moscow: Kluwer Academic/ Plenum Publishers.

Diekmann B, Kuhn G, Gersonde R, Mackensen A. 2004. Middle Eocene to early Miocene environmental changes in the sub-Antarctic Southern Ocean: evidence from biogenic and terrigenous depositional patterns at ODP Site 1090. Global and Planetary Change 40: 295-313.

Duchassaing De Fonbressin P, Michelotti G. 1864. Spongiaires de la mer Caraïbe. Natuurkundige verhandelingen van de Hollandsche maatschappij der wetenschappen te Haarlem 21: 1-124.

Edwards AR. (compiler) 1991. The Oamaru diatomite. New Zealand Geological Survey Paleontological Bulletin 64: 260.

Exton NF, Kenet JP, Malone MJ, Brinkhuis H, Chaproniere GCH, Ennyu A, Fothergill P, Fuller MD, Grauert M, Hil PJ, nineteen others 2001. The Tasmanian Gateway: Cenozoic climatic and oceanographic development, sites 1168-1172. Proceedings of the Ocean Drilling Program, Initial Reports 189: 1-98.

Frisone V, Pisera A, Hajdu E, Preto N, Zorzi F, Zorzin R. 2014. Isolated spicules of Demospongiae from Mt. Duello (Eocene, Lessini Mts, northern Italy): preservation, taxonomy and sedimentary environment. Facies 60: 883-904.

Fromont J, Usher KL, Sutton DC, Toze S, Kuo J. 2008. Species of the sponge genus Chondrilla (Demospongiae: Chondrosida: Chondrillidae) in Australia. Records of the Western Australian Museum 24: 469-486.

Gammon PR, James NP, Pisera A. 2000a. Eocene spiculites and spongolites in south-western Australia: Not deep, not polar, but shallow and warm. Geology 28: 855-858.

Gammon PR, James NP, Bone Y, Clarke JDA. 2000b. Sedimentology and lithostratigraphy of Upper Eocene sponge-rich sediments, southern Western Australia. Australian Journal of Earth Sciences 47: 1087-1103.

Goldfuss A. 1826-1833. Petrefacta Germaniae tam ea, quae in museo Universitatis Regiae Borussicae Fredericae Wilhelmiae Rhenanae servantur quam alia quaecunque in $\mathrm{Mu}$ seis Hoeninghausiano. Muensteriano aliisque extant Iconibus et Descriptionibus Illustrata. Erster.

Gray JE. 1867. Notes on the arrangement of sponges, with the descriptions of some new genera. Proceedings of the Zoological Society of London 1867: 492-558.

Hall J, Clarke JM. 1899. A memoir on the Paleozoic reticulate sponges constituting the family Dictyospongidae. Memoir of the New York State Museum 2: 350.

Hamdi B, Brasier MD, Jiang Z. 1989. Earliest skeletal fossils from Precambrian-Cambrian boundary strata, Elburz Mountains. Iran Geological Magazine 126: 283-289.

Hechtel GJ. 1965. A systematic study of the Demospongiae of Port Royal, Jamaica. Bulletin of the Peabody Museum of Natural History 20: 1-103.

Hentschel E. 1911. Tetraxonida. 2. Teil. Pp. 279-393 in: Michaelsen W, Hartmeyer R, eds, Die Fauna Südwest-Australiens. Ergebnisse der Hamburger südwest-australischen Forschungsreise 1905., Fischer: Jena.

Hentschel E. 1912. Kiesel- und Hornschwämme der Aru- und Kei-Inseln. Abhandlungen herausgegeben von der Senckenbergischen naturforschenden Gesellschaft 34: 293 448.
Hentschel E. 1914. Monaxone Kieselschwämme und Hornschwämme der Deutschen Südpolar-Expedition 1901-1903. Deutsche Südpolar-Expedition, 1901-03 Forschungsreise 1905, Fischer: Jena, 15: 35-141.

Hinde GJ. 1883. Catalogue of the fossil sponges in the Geological Department of the British Museum (Natural History). London: Taylor and Francis.

Hinde GJ. 1893. A monograph of the British fossil sponges. Part III. Sponges of the Jurassic strata. Palaeontolical Society Monograph, 189-254.

Hinde GJ, Holmes WM. 1892. On the sponge remains in the Lower Tertiary Strata near Oamaru, Otago, New Zealand. Journal of the Linnean Society of London 24: 177-262.

Hooper JNA. 1998. Sponge biodiversity, distribution and biogeography. In: Lévi C, ed. Sponges of the New Caledonian lagoon. Editions de l'Orstom, Paris: Collection Faune et Flore Tropicales.

Hooper JNA. 2002a. Family Acarnidae Dendy, 1922. Pp. 412431 in: Hooper JNA, van Soest RWM, eds, Systema Porifera. Guide to the classification of sponges. New York, Boston, Dordrecht, London, Moscow: Kluwer Academic/ Plenum Publishers.

Hooper JNA. 2002b. Family Raspailiidae Hentschel, 1923. Pp. 469-510 in: Hooper JNA, van Soest RWM, eds, Systema Porifera. Guide to the classification of sponges. New York, Boston, Dordrecht, London, Moscow: Kluwer Academic/ Plenum Publishers.

Hooper JNA, Kennedy JA. 2002. Small-scale patterns of sponge biodiversity (Porifera) on Sunshine Coast reefs, eastern Australia. Invertebrate Systematics 16: 637-653.

Hooper JNA, Soest RWM, van, eds. 2002. Systema Porifera: $a$ guide to the classification of sponges. New York, Boston, Dordrecht, London, Moscow: Kluwer Academic/Plenum Publishers, 1-1101, 1103-1706.

Hooper JNA, Ekins M. 2005. Collation and validation of museum collection databases related to the distribution of marine sponges in Northern Australia (Contract National Oceans Office C2004/020). Report to the National Oceans Office, Australia (Contract number C2004/020), 235 pp.

Hooper JNA, Lévi C. 1994. Biogeography of Indo-west Pacific sponges: Microcionidae, Raspailiidae, Axinellidae. Pp. 191212 in: Soest van RWM, Kempen TGM, van, Braekman J-C, eds, Sponges in Time and Space, Rotterdam: Balkema.

Hooper JNA, Wiedenmayer F. 1994. Porifera. In: Zoological Catalogue of Australia 12. Wells A, ed, Melbourne: CSIRO.

James NP, Bone Y. 2000. Eocene cool-water carbonate and biosiliceous sedimentation dynamics, St. Vincent Basin, South Australia. Sedimentology 47: 761-786.

James NP, Bone Y. 2008. Carbonate-biosiliceous sedimentation in Early Oligocene estuaries during a time of global change, Port Willunga Formation, St. Vincent Basin, Southern Australia. Pp. 231-253 in: Lukasic J, Simo JA, eds, Controls on carbonate platform and reef development. SEPM Special Publication 89.

Kaesler RL. 2004. Treatise on Invertebrate Paleontology, Part E, (Revised) Porifera, 3. Geological Society of America and The University of Kansas Press, Kansas: Boulder and Lawrence.

Kelly M, Buckeridge JS. 2005. An early Paleogene sponge fauna, Chatham Island, New Zealand. New Zealand Journal of Marine and Freshwater Research 39: 899-914. 
Kelly M, Edwards AR, Wilkinson MR, Alvarez B, De Cook SC et al. 2009. Phylum Porifera sponges. Pp. 1-46 in: Gordon DP, ed, New Zealand inventory of biodiversity 1. Radiata, Lophotrochozoa, Deuterostomia. Christchurch: Canterbury University Press.

Klautau M, Russo CAM, Lazoski C, Boury-Esnault N, Thorpe JP, Sole-Cava AM. 1999. Does cosmopolitanism result from overconservative systematics? A case study using the marine sponge Chondrilla nucula. Evolution 53: 1414-1422.

Koltun VM. 1959. Siliceous horny sponges of the northern and far eastern seas of the U.S.S.R. Zoologicheskim Muzeem Akademii Nauk 67: 1-236. (in Russian)

Koltun VM. 1961. Spicules of siliceous sponges in Upper Cretaceous and Paleogene sediments of the northern Ural. Paleontological Journal 1: 61. (in Russian)

Laubenfels MW, De. 1955. Porifera. In: Moore RC, ed, Treatise on Invertebrate Paleontology. Part E, Archaeocyatha and Porifera. New York: Geological Society of America and University of Kansas Press, and Kansas: Lawrence.

Lendenfeld R, Von. 1886 [1885]. A monograph of the Australian sponges. Part IV. Preliminary report on the Australian Myxospongiae. Proceedings of the Linnean Society of New South Wales 10: 3-22.

Lévi C, Lévi, P. 1983. Eponges Tétractinellides et Lithistides bathyales de Nouvelle-Calédonie. Bulletin du Muséum national d'Histoire naturelle 5: 101-168.

Lévi C, Lévi P. 1989. Spongiaires (Musorstom 1 and 2). Pp. $25-$ 103 in: Forest J, ed, Résultats des Campagnes Musorstom. Mémoires du Muséum national d'Histoire naturelle (A, Zoologie) 4143.

Leys SP, Mackie GO, Reiswig HM. 2007. The biology of glass sponges. Advances in Marine Biology 52: 1-145.

Leys SP, Wilson K, Holeton C, Reiswig HM, Austin WC, Tunnicliffe V. 2004. Patterns of glass sponge (Porifera, Hexactinellida) distribution in coastal waters of British Columbia, Canada. Marine Ecology Progress Series 283: 133-149.

Łukowiak M, Pisera A, O’Dea A. 2013. Do spicules in sediments reflect the living sponge community? A test in a Caribbean shallow water lagoon. Palaios 28: 373-385.

Łukowiak M, Pisera A, Schlögl J. 2014. Siliceous sponges from the bathyal deposits of the Late Early Miocene Vienna Basin (Central Paratethys, Slovakia). Paläontologische Zeitschrift 88: 263-277.

Łukowiak M. 2015. Reconstruction of the Late Eocene "soft" sponge fauna of southern Australia. Zootaxa 3917: 1-65.

Maldonado M. 2002. Family Pachastrellidae. Pp. 141-162 in: Hooper JNA, van Soest RWM, eds, Systema Porifera: $a$ guide to the classification of sponges. New York, Boston, Dordrecht, London, Moscow: Kluwer Academic/Plenum Publishers.

Matteucci R, Russo A. 2005. The Middle Eocene siliceous sponges from Val di Chiampo (Lessini Mountains, northern Italy). Annali dell'Università degli Studi di Ferrara Museologia Scientifica e Naturalistica, 51-62.

McDonald JI, Fromont J. 2004. Sponge and ascidian communities of the Recherche Archipelago 1-3. Report to CSIRO Strategic Research Fund for the Marine Environment, 111117.

McDonald I, Kendrick G, Fromont J. 2005. Spatial patterns in sessile benthic sponge and ascidian communities of the Recherche Archipelago. SRFME Interim Final Report, 72-78.
McEnnulty FR, Gowlett-Holmes KL, Williams A, Althaus F, Fromont J, Poore GCB, O'Hara TD, Marsh L, Kott P, SlackSmith S, Alderslade P, Kitahara MV. 2011. The deepwater megabenthic invertebrates on the western continental margin of Australia (100-1500 m depths): composition, distribution and novelty. Records of the Western Australian Museum 80: 1-191.

McGowran B, Alley NF. 2008. History of the Cenozoic St Vincent Basin in South Australia. In: Natural History of Gulf St. Vincent. Shepherd SA, Bryars S, Kirkegaard I, Harbison P, Jennings JT, eds. Royal Society of South Australia, Occasional Publications 8: 13-28.

McLoughlin S, McNamara K. 2001. Ancient Floras of Western Australia. Publication of the Department of Earth and Planetary Sciences, Western Australian Museum, 42 pp.

Morrow C, Cárdenas P. 2015. Proposal for a revised classification of the Demospongiae (Porifera). Frontiers in Zoology 12: 7 .

Mostler H. 1972. Die Spiculae triassischer Poriferen. Innsbruck: Mitteilungen Gesellschaft der Geologie- und Bergbaustudenten in Österreich 21/1 and 2, 539-546.

Mostler H. 1976. Poriferenspiculae aus der alpinen Trias. Innsbruck: Geologisch-Paläontologische Mitteilungen 6: 1-42.

Mostler H. 1994. Der erste Nachweis von agelasiden Schwämmen (Demospongiae) aus dem Jungpaläozoikum. Abhandlungen der Geologischen Bundesanstalt 50: 341-352.

Munro MHG, Blunt JW, Dumdei EJ, Hickford SJH, Lill RE, Li S, Battershill CN. Duckworth AR. 1999. The discovery and development of marine compounds with pharmaceutical potential. Journal of Biotechnology 70: 15-25.

Ozawa T, Köhler F, Reid DG, Glaubrecht M. 2009. Tethyan relicts on continental coastlines of the northwestern Pacific Ocean and Australasia: Molecular phylogeny and fossil record of batillariid gastropods (Caenogastropoda, Cerithioidea). Zoologica Scripta 38: 503-525.

Pisera A. 1997. Upper Jurassic siliceous sponges from the Swabian Alb: taxonomy and paleoecology. Palaeontologia Polonica 57: 3-216.

Pisera A. 1999. Postpaleozoic history of the siliceous sponges with rigid skeleton. Memoires of the Queensland Museum 44: 473-478.

Pisera A. 2006. Palaeontology of sponges. A review. Canadian Journal of Zoology 84: 242-262.

Pisera A, Busquets P. 2002. Eocene siliceous sponges from the Ebro Basin (Catalonia, Spain). Geobios 35: 321-346.

Pisera A, Lévi C. 2002. 'Lithistid' Demospongiae. Pp. 299-301 in: Hooper JNA, van Soest RWM, eds, Systema Porifera: a guide to the classification of sponges. New York, Boston, Dordrecht, London, Moscow: Kluwer Academic/ Plenum Publishers

Pisera A, Hladilová S. 2003 (2004). Siliceous sponge spicules from Karpatian of the Carpathian Foredeep in Moravia. Pp. 189-191 in: Brzobohaty R, Cicha I, Kovac M, Rogl F, eds, The Karpatian. A lower Miocene stage of the Central Paratethys. Brno.

Pisera A, Cachao M, da Silva, C. 2006. Siliceous sponge spicules from the Miocene Mem Moniz marls (Portugal) and their environmental significance. Rivista Italiana di Paleontologia 112: 287-299.

Pisera A, Bitner MA. 2007. The sponge genus Brachiaster (Pachastrellidae, Demospongiae) and its first known fossil 
representative, from late Eocene of southwestern Australia. Alcheringa 31: 365-373.

Pisera A, Vacelet J. 2010. Lithistid sponges from submarine caves in the Mediterranean: taxonomy and affinities. Scientia Marina 75: 17-40.

Pomponi SA, Kelly M, Reed J, Wright A. 2001. Diversity and bathymetric distribution of lithistid sponges in the tropical western Atlantic region. Bulletin of the Biological Society of Washington 10: 344-353.

Poore GCB. 1995. Biogeography and diversity of Australia's marine biota. Pp. 49-63 in: Muldoon J, ed, Towards a Marine Regionalisation for Australia. Ocean Rescue 2000 Workshop Series 1. Great Barrier Reef Marine Park Authority. Proceedings of a Workshop held in Sydney, New South Wales.

Quaglio F, Anelli LE, dos Santos PR, Warren LV. 2007. The Cenozoic diversity of Antarctic bivalves does not reflect Southern Ocean environmental changes after the Antarctic thermal isolation. Oecologia Brasiliensis 11: 29-36.

Quenstedt FA. 1878. Petrefactenkunde Deutschlands. FuesVerlag, Leipzig, $558 \mathrm{pp}$.

Rauff H. 1893-1895. Paleospongiologie. Palaeontographica 40: 1-395.

Reid REH. 1968. Bathymetric distribution of Calcarea and Hexactinellida in the present and the past. Geological Magazine 105: 546-559.

Reitner J, Mehl D. 1995. Early Paleozoic diversification of sponges: New data and evidences. Geologisch-Paläontologische Mitteilungen Innsbruck 20: 335-347.

Roemer CF. 1860. Die silurische Fauna des westlichen Tennessee: Eine Palaeontologische Monographie. Breslau: Edvard Trewendt Verlag.

Rosell D, Uriz MJ. 2002. Excavating and endolithic sponge species (Porifera) from the Mediterranean: species descriptions and identification key. Organisms, Diversity \& Evolution, 1-32.

Round FE, Crawford RM, Mann DG. 1990. The Diatoms: Biology and morphology of the genera. Cambridge: Cambridge University Press.

Rützler K. 2002a. Family Alectonidae Rosell, 1996. Pp. 281290 in: Hooper JNA, van Soest RWM, eds, Systema Porifera: a guide to the classification of sponges. New York, Boston, Dordrecht, London, Moscow: Kluwer Academic/ Plenum Publishers.

Rützler K. 2002b. Family Placospongiidae Gray, 1867. Pp. 196200 in: Hooper JNA, van Soest RWM, eds, Systema Porifera: a guide to the classification of sponges. New York, Boston, Dordrecht, London, Moscow: Kluwer Academic/ Plenum Publishers.

Rützler K. 2002c. Family Spirastrellidae Ridley \& Dendy, 1886. Pp. 220-223 in: Hooper JNA, van Soest RWM, eds, Systema Porifera: a guide to the classification of sponges. New York, Boston, Dordrecht, London, Moscow: Kluwer Academic/ Plenum Publishers.

Rützler K, Duran S, Piantoni C. 2007. Adaptation of reef and mangrove sponges to stress: evidence for ecological speciation exemplified by Chondrilla caribensis new species (Demospongiae, Chondrosida). Marine Ecology 28: 95-111.

Sarà M, Bavestrello G. 1995. Tethya omanensis, a remarkable new species from an Oman cave (Porifera, Demospongiae). Bolletino di Zoologia 62: 23-27.
Sim-Smith C, Kelly M. 2011. Two new genera in the family Podospongiidae (Demospongiae: Poecilosclerida) with eight new Western Pacific species. Zootaxa 2976: 32-54.

Schmidt O. 1862. Die Spongien des adriatischen Meeres. Leipzig: Wilhelm Engelmann.

Schmidt O. 1870. Grundzüge einer Spongien-Fauna des atlantischen Gebietes. Leipzig: Wilhelm Engelmann.

Soest van RWM. 1988. Tetrapocillon atlanticus n. sp. (Porifera, Poecilosclerida) from the Cape Verde islands. Beaufortia 38: 37-46.

Soest van RWM. 1994. Demosponge distribution patterns. Pp. 213-224 in: Soest van RWM, Kempen van TMG, Braekman J-C, eds, Sponges in time and space. Rotterdam: Balkema.

Soest van RWM. 2002a. Family Suberitidae Schmidt, 1870. Pp. 227-244 in: Hooper JNA, van Soest RWM, eds, Systema Porifera: a guide to the classification of the sponges. New York, Boston, Dordrecht, London, Moscow: Kluwer Academic / Plenum Publishers.

Soest van RWM. 2002b. Family Crellidae Dendy, 1922. Pp. 556-566 in: Hooper JNA, van Soest RWM, eds, Systema Porifera: a guide to the classification of sponges. New York, Boston, Dordrecht, London, Moscow: Kluwer Academic / Plenum Publishers.

Soest van RWM. 2002c. Family Crambeidae Lévi, 1963. Pp. 547-555 in: Hooper JNA, van Soest RWM, eds, Systema Porifera: a guide to the classification of sponges. New York, Boston, Dordrecht, London, Moscow: Kluwer Academic / Plenum Publishers.

Soest van RWM. 2002d. Family Coelosphaeridae Dendy, 1922. Pp. 528-546 in: Hooper JNA, van Soest RWM, eds, Systema Porifera: a guide to the classification of sponges. New York, Boston, Dordrecht, London, Moscow: Kluwer Academic / Plenum Publishers.

Soest van RWM. 2002e. Family Agelasidae Verrill, 1907. Pp. 819-823 in: Hooper JNA, van Soest RWM, eds, Systema Porifera: a guide to the classification of sponges. New York, Boston, Dordrecht, London, Moscow: Kluwer Academic / Plenum Publishers.

Soest van RWM, Hajdu E. 2002. Family Mycalidae Lundbeck, 1905. Pp. 669-690 in: Hooper JNA, van Soest RWM, eds, Systema Porifera: a guide to the classification of sponges. New York, Boston, Dordrecht, London, Moscow: Kluwer Academic / Plenum Publishers.

Soest van RWM, Beglinger EJ. 2008. Tetractinellid and hadromerid sponges from the Sultanate of Oman. Zoologische Mededelingen Leiden 82: 749-790.

Soest van RWM, Hooper JNA. 2002a. Family Samidae Sollas, 1886. Pp. 99-101 in: Hooper JNA, van Soest RWM, eds, Systema Porifera: a guide to the classification of sponges. New York, Boston, Dordrecht, London, Moscow: Kluwer Academic/ Plenum Publishers.

Soest van RWM, Hooper JNA. 2002b. Family Calthropellidae Lendenfeld, 1906. Pp. 127-133 in: Hooper JNA, van Soest RWM, eds, Systema porifera: a guide to the classification of sponges. New York, Boston, Dordrecht, London, Moscow: Kluwer Academic / Plenum Publishers.

Soest van RWM, Boury-Esnault N, Hooper JNA, Rützler K, de Voogd NJ, Alvarez de Glasby B, Hajdu E, Pisera AB, Manconi R, Schoenberg C, Janussen D, Tabachnick KR, Klautau M, Picton B, Kelly M, Vacelet J, Dohrmann M, Díaz M. 
2013. World Porifera database. http://www.marinespecies. org/porifera (accessed 2014-11-05).

Sollas WJ. 1878. On two new and remarkable species of Cliona. Annals and Magazine of Natural History 1: 54-66.

Sollas WJ. 1888. Report on the Tetractinellida collected by H.M.S. Challenger, during the years 1873-1876. Report on the Scientific Results of the Voyage of H.M.S. Challenger, 1873-1876. Zoology 25: 1-458.

Sorokin SJ, Currie DR. 2009. The distribution and diversity of sponges in Spencer Gulf. Report to the Nature Foundation South Australia. SARDI Aquatic Sciences Publication No. F2008/001153-1, SARDI Research Report Series No. 334, Adelaide.

Topsent E. 1890. Notice préliminaire sur les spongiaires recueillis durant les campagnes de l'Hirondelle. Bulletin de la Société zoologique de France 15: 26-32, 65-71.

Topsent E. 1896. Campagnes du Yacht Princesse Alice. Sur deux curieuses Espérellines des Açores. Bulletin de la Société Zoologique de France 21: 147-150.

Topsent E. 1897. Spongiaires de la Baie d'Amboine. (Voyage de MM. M. Bedot et C. Pictet dans l'Archipel Malais). Revue Suisse de Zoologie 4: 421-487.

Topsent E. 1898. Eponges nouvelles des Açores. (Première serie). Mémoires de la Société Zoologique de France 11: 225-255.

Topsent E. 1904. Spongiaires des Açores. Résultats des campagnes scientifiques accomplies par le Prince Albert I. Monaco 25: 1-280.

Uriz MJ. 2002a. Family Geodiidae Gray, 1867. Pp. 134-140 in: Hooper JNA, van Soest RWM, eds, Systema Porifera: a guide to the classification of sponges. New York, Boston, Dordrecht, London, Moscow: Kluwer Academic/ Plenum Publishers.

Uriz MJ. 2002b. Family Thrombidae Sollas, 1888. Pp. 163-164 in: Hooper JNA, van Soest RWM, eds, Systema Porifera: a guide to the classification of sponges. New York, Boston, Dordrecht, London, Moscow: Kluwer Academic/ Plenum Publishers.

Uriz MJ. 2002c. Family Ancorinidae Schmidt, 1870. Pp. 108126 in: Hooper JNA, van Soest RWM, eds, Systema Porifera: a guide to the classification of sponges. New York, Boston, Dordrecht, London, Moscow: Kluwer Academic/ Plenum Publishers.

Vacelet J. 1988. Indications de profondeur donnés par les Spongiaires dans les milieux benthiques actuels. Géologie Méditerranéenne 15: 13-26.
Vacelet J, Vasseur P. 1971. Éponges des récifs coralliens de Tuléar (Madagascar). Téthys, Supplément 1: 51-126.

Vacelet J, Vasseur P, Lévi C. 1976. Spongiaires de la pente externe des récifs coralliens de Tuléar (Sud-Ouest de Madagascar). Mémoires du Muséum national d'Histoire naturelle (A, Zoologie) 49: 1-116.

Wiedenmayer F. 1994. Contribution of the knowledge of postPaleozoic neritic and archibenthal sponges (Porifera). Schweizerische Paläontologische Mitteilungen 116: 1-147.

Wilson HV. 1925. Silicious and horny sponges collected by the U.S. Fisheries Steamer 'Albatross' during the Philippine Expedition, 1907-10. Washington.

Wörheide G, Degnan BM, Hooper JNA, Reitner J. 2002. Phylogeography and taxonomy of the Indo-Pacific reef cave dwelling coralline demosponge Astrosclera willeyana new data from nuclear internal transcribed spacer sequences. Pp. 339-346 in: Moosa KM, Soemodihardjo S, Soegiarto A, Romimohtarto K, Nontji A, Soekarno A, Suharsono, eds, Proceedings of the 9th International Coral Reef Symposium, Jakarta: Ministry for Environment, Indonesian Institute of Sciences, International Society for Reef Studies.

Xavier JR, Rachello-Dolmen PG, Parra-Velandia F, Schönberg CHL, Breeuwer JAJ, Soest van RWM. 2010. Molecular evidence of cryptic speciation in the "cosmopolitan" excavating sponge Cliona celata (Porifera, Clionaidae). Molecular Phylogenetics and Evolution 56: 13-20.

Zezina ON. 2009. Relicts of the Tethyan fauna in the Recent oceans. Paleontological Journal 43: 877-880.

Zittel KA. 1877. Studien über fossile Spongien. I: Hexactinellidae. Abhandlungen der Mathematisch-Physikalischen Classe der Königlich-Bayerischen Akademie der Wisseneschaften, München 13: 1-63.

Internet sources:

Atlas of living Australia: http://www.ala.org.au [visited 28 November 2014]

Received: 30 March 2015

Revised and accepted: 3 August 2015

Published online: 12 January 2016

Editor: R.W.M. van Soest 